UC-NRL

(1)

C $2 \quad 928 \quad 973$ 

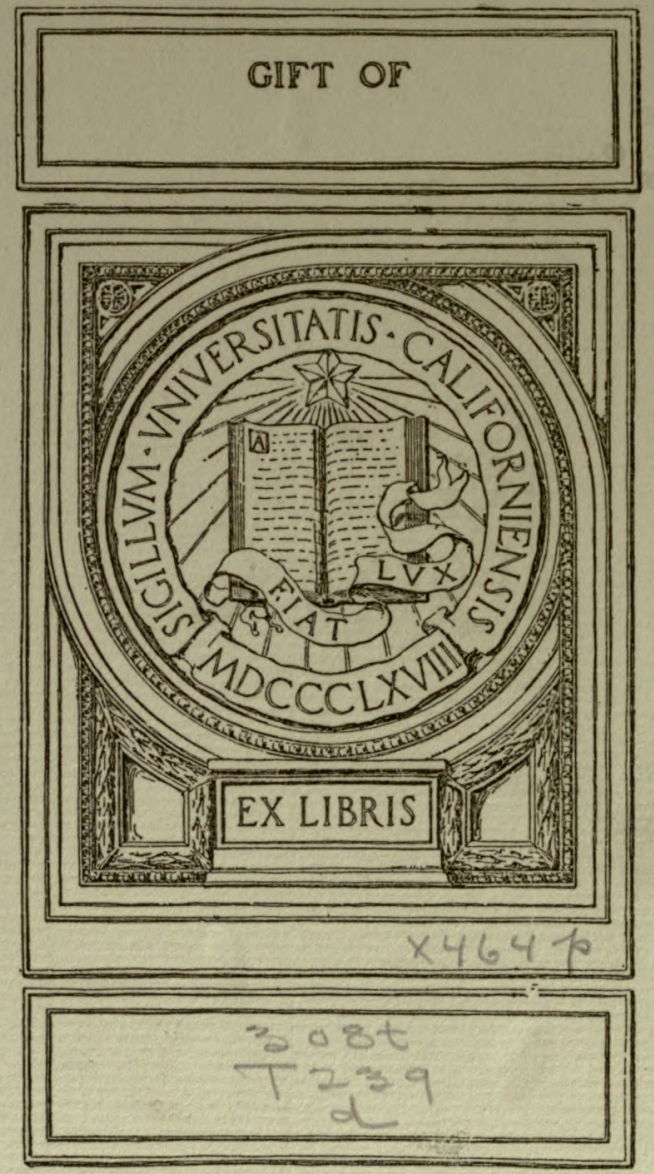





\section{DEMONSTRATION OF THE FUNCTION OF}

\section{THE NEUROMOTOR APPARATUS IN}

\section{EUPLOTES BY THE METHOD}

\section{OF MICRODISSECTION}

A THESIS ACCEPTED IN PARTIAL SATISFACTION OF THE REQUIREMENTS FOR THE DEGREE OF DOCTOR OF PHILOSOPHY

AT THE UNIVERSITY OF CALIFORNIA

BY

CHARLES VINCENT TAYLOR

DECEMBER, 1918

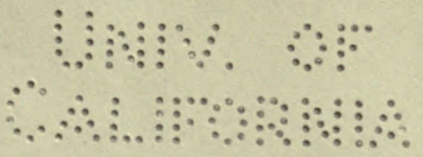




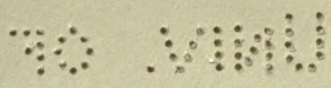
a औ 


\section{UNIVERSITY OF CALIFORNIA PUBLICATIONS}

Vol. 19 , No. 13, pp. $403-470$, plates $29-33,2$ text figures October 23,1920

\section{DEMONSTRATION OF THE FUNCTION OF THE NEUROMOTOR APPARATUS IN EUPLOTES BY THE METHOD OF MICRODISSECTION}

BY

CHARLES V. TAYLOR 


\section{UNIVERSITY OF CALIFORNIA PUBLIOATIONS}

Note.-The University of Callfornia Publications are offered in exchange for the publl. cations of learned societies and institutions, universities, and libraries. Complete lists of all the publications of the University will be sent upon request. For sample copies, lists of publications or other information, address the MANAGER OF THE UNIVIRSITY PRESS, BERKELEY, CALIFORNIA, U. S. A. All matter sent in exchange should be addressed to THE EXCHANGE DEPARTMENT, UNIVERSTTY LIBRARY, BEREELEY, CATIFORNIA, U. S. A.

WILLIAM WESLEY \& SONS, LONDON

Agent for the series in American Archaeology and Ethnology, Botany, Geology, Physiology, and Zoology.

ZOOLOGY.-W. E. Ritter and C. A. Kofoid, Editors.

This series contains the contributions from the Department of Zoology, from the Marine Laboratory of the Scripps Institution for Blological Research, at La Jolla, California, and from the California Museum of Vertebrate Zoology in Berkeley.

Cited as Univ, Calif. Publ. Zool.

Volume 1, 1902-1905, 317 pages, with 28 plates $\$ 3.50$

Volume 2, 1904-1906, xvil + 382 pages, with 19 plates ................................................. \$3.50

Volume 3, 1906-1907, 383 pages, with 23 plates ........................................................... $\$ 3.50$

Volume 4, 1907-1908, 400 pages, with 24 plates ............................................................ \$3.50

Volume 5, 1908-1910, 440 pages, with 34 plates .............................................................. \$3.50

Volume 6, 1908-1911, 478 pages, with 48 plates .............................................................. \$3.50

Volume 7, 1910-1912, 146 pages, with 12 plates ............................................................ \$3.50

Volume 8, 1911, 357 pages, with 25 plates .......................................................................... \$3.50

Volume 9, 1911-1912, 365 pages, with 21 plates ................................................................. \$3.50

Volume 10, 1912-1913, 417 pages, with 10 plates ............................................................. \$3.50

Volume 11, 1912-1914, 538 pages, with 26 plates ........................................................ \$5.00

Volume 12, 1913-1916, 558 pages, with 22 plates ............................................................ $\$ 5.00$

Volume 13, 1914-1916, 529 pages, with 39 plates ............................................................. \$5.00

Volume 14, 1914-1918, 452 pages, with 60 plates ............................................................... $\$ 5.00$

Volume 15, 1915-1916, 360 pages, with 38 plates .................................................................. \$1.00

Volume 16, 1915-1917, 522 pages, with 46 plates ............................................................... \$5.00

Volume 17, 1916-1918, 545 pages, with 24 plates ............................................................. \$5.00

Vol. 17. 1. Diagnosis of Seven New Mammals from East-Central California, by Joseph Grinnell and Tracy I. Storer. Pp. 1-8.

2. A Now Bat of the Genus Myotis from the High Sierra Nevada of Callfornia, by Hilda Wood Grinnell. Pp. 9-10.

Nos. 1 and 2 in one cover. Angust, 1916

3. Spelerpes platycephalus, a New Alpine Salamander from the Yosemite National Paris, California, by Charles Lewis Camp. Pp. 11-14. September, 1916

4. A New Spermophlle from the San Jeaquin Valley, Calffornia, with Notes cn Ammospermophilus nelsoni nelsoni Merriam, by Walter P. Taylor. Pp. $15-20,1$ figure in text. October, 1916

5. Habits and Food of the Roadrunner in Callfornia, by Harold C. Bryant. Pp. 21-58, plates 1-4, 2 figures in text. October, 1916

6. Description of Bufo canorus. a New Toa from the Yosemite National Park. by Charles Lewis Camp. Pp. 59-62, 4 figures in text. November, $1916 . . .$.

7. The Subspecies of Sceloporis occidentalis, with Description of a Now Form from the Sierra Nevada and Systematic Notes on Other Callfornia Iizards, by Charles Lewis Camp. Pp. 63-74. December, 1916

8. Osteological Relationships of Three Specles of Beavers, by $\mathbf{E}$. Harvey Holden. Pp. 75-114, plates 5-12, 18 text figures. March, 1917

9. Notes on the Systematic Status of the Toads anc Frogs of California, by Charles Lewis Camp. Pp. 1.15-125, 3 text figures. February, 1917

10. A Distributional List of the Amphibians and Reptiles of Callernia, by Joseph Grinnell and Charles tewis Camp. Pp. 127-208, 14 flgures in text. July, 1917 
UNIVERSITY OF CALIFORNIA PUBLICATIONS

IN

ZOOLOGY

Vol. 19 , No. 13 , pp. $403-470$, plates $29-33,2$ text figures October 23,1920

\section{DEMONSTRATION OF THE FUNCTION OF THE NEUROMOTOR APPARATUS IN EUPLOTES BY THE METHOD OF MICRODISSECTION}

BY

CHARLES V. TAYLOR

\section{CONTENTS}

Introduction
Acknowledgments
Method and material
Moist ehambers
Binocular microseope
Glass needles
Control
Staining
Material
The living organism
Endoplasm
Eetoplasm
Macronueleus
Mieronucleus
Contractile vacuole
Anal aperture
Cirri
Membranelles
Neuromotor apparatus
Movements
Experimental
Pellicle
Fibrillar system
Transections
Exeisions
Ineisions


$\because \vdots \vdots$

\section{INTRODUCTION}

Protozoa are commonly regarded as representatives of the most primitive and simplest forms of life. The most salient feature of the plyyum is eoneerled to be their unicellularity, each individual being the morphological equivalent of a single eell. That these characteristies indiscriminately applied to this very large and diversified group of organisms are not only inadequate but somewhat misleading is partieularly evident from several recent investigations on various flagellates and eiliates. The results of these researches point toward complexity rather than simplieity and stimulate inquiry into the nature and function of eertain intracytoplasmie struetures that these animals possess, whieh may indieate an organization more highly evolved than is usually assumed.

These structures in both flagellates and ciliates are intimately associated with ectoplasmie organelles (flagella, cilia, eirri, ete.), a fact which strongly suggests that they share some rôle in the animal's motor meehanism. Accordingly, investigators are generally agreed in designating the structures with their attached organelles "the motor apparatus."

Of the organisms possessing such a motor apparatus a larger number of flagellates than of eiliates has been studied and eomparatively deseribed. In the former elass a series has been worked out that indieates a progressive evolution of this mechanism. A simple type of motor apparatus appears in the biflagellate stage of the soil amoeba, Naeglevia gruberi (Seliardinger). It consists of two flagella attached to a basal corpusele, the blepharoplast, which in turn is eomeeted lyy a fine fibril to the nueleus. This organism spends most of its exeysted life as an amoeboid trophozoite, but it may beeome transformed for a brief period of twenty-four hours or less into a very active flagellate. This interesting change has been described by Whitmole (1911), Alexeieff (1912), and more completely by Wilson (1916), who has shown that variations in temperature. media, and other factors may induee the eliange. The actual transformation may be followed in living forms and its stages analyzed in fixed unaterial.

It was thus observed that the motor apparatus arises by an outgrowth from the karyosome, "presumably from the centriole," Wilson 
states, "which crosses the clear nuclear zone, energes through the nuelear membrane" whence arises a plastic thread, the rhizoplast, that ends near the periphery in the blepharoplast. The two flagella grow out fiom this blepharoplast.

The origin of the apparatus from the eentriole is not elearly established. This eentriole ean he seen within the karyosone during the entire development of the flagella, althongl its division may give rise to these structures. Dr. Swezy (1916) offers a eritical disenssion of this point.

1 less primitive motor apparatus is met with in Prouazclia lacertae (Grassi), a parasitie flacellate found within the intestine of amphibians. The form is deseribed by Alexeicft (1912), and Janicki (1915), and its motor apparatus eritically compared with that of other flagellates by Swezy (1916). One stage in the life-eyele shows a motor meeluanism quite similar to that of the flagellated soil amoeba, including two flagella attached to the blepharoplast which is eomneeted by the rhizoplast to the nueleus. This condition beeomes modified by an enlarged blepharoplast that elongates and buds off its larger portion to form the parabasal body. The latter structure remains attached to the bleplaroplast by a rhizoplast and so shares a part in an integrated motor apparatus that is typieal for several other forms of the series. The parabasal body is deseribed in some protozoological literature under the name "kinetonueleus." Protozoologists using this nomenclature designate the nueleus "trophomeleus." The former is held to be a produet of the latter, is eomposed of nuclear ehromatin, and divides mitotieally. But more reeent researehes do not substantiate these elaims (Doflein, 1911. Kofoid, 1915, Swezy, 1916). 'The origin of the body, as in Prowazcita lacertae, from the blepharoplast to which it remains attached, is a fact whieh in itself establishes the strueture as a component of the motor mechanism. In this relation it has been regarded as an aceessory kinetic reservoir which supplies oxidizable material to the locomotor organelles (Kofoid and Swezr, 1915).

In Trypanoplasma congri (Martin, 1913), oceurs a furtlee complexity in the motor apparatus with the attachment of a trailing flagellum to the body by a fairly well developed membrane. It is also signifieant that the parabasal body is here considerably elongated, extending from near the blepharoplast lateral to and beyond the nueleus. These variations are regarded (Swezy, 1916) as representing a step in the evolutionary series toward the conditions that obtain 
in eertain trichomonads. Of this gemus, Trichomonas augusta (Kofoid and Swezy, 1915) possesses a motor mechanism to whose blepharoplast are attached: (1) three equal anterior flagella, (2) one intracytoplasmic flagellum, the axostyle, (3) a trailing flagellum attached laterally along the margin of the undulating membrane, and (4) an elongated, chromatoidal rod, the parabasal body, which lies along the proximal edge of the undulating membrane. Recalling the occurrenee of a trailing flagellum and the elongated parabasal body in Trypanoplasma congri, an homology between these and structures (3) and (4) in Trichomonas augusta appears obvious.

But the eomplexity of the motor apparatus does not end with the triehomonads. In the other geuus of the Polymastjgina, the Octomitidae, appear fnrther advanees in the series. An amphibian parasite, Octomitus dujardini (Dobell, 1909) claims for its motor mechanism a pair each of blepharoplasts, parabasal bodies and axostyles, and three anterior flagella attaehed to each blepharoplast. Omitting the undulating membranes, Octomitus is really the equivalent of two trielomonads. This duplex eondition does, in fact, become complete in Giardia (Kofoid and Cliristiansen, 1915b, Boeek, 1917), the remarkable motor mechanism of which rivals in complexity that about to be deseribed for eertain eiliates. There is a duplication here of each structure found in the apparatus of Triclomonas. But with the eonneetion of the two blepharoplasts by a commissure and with a chiasmal erossing of the anterior lateral fiagella, two organisms become integrated into one individual (Kofoid and Christiansen, 1915b).

It was suggested by Professor Kofoid (Kofoid and Christiansen, $1915 b$ ) that this integrating fibrillar complex in Giardia, assoeiated with the blepharoplasts, parabasal bodies and the very active organelles of locomotion, was neuromotor in function. To the system he assigned the name "neuromotor apparatus" which has sinee been applied to homologous fibrillar systems in other flagellates of the above series.

The series indicated in the foregoing examples has been considerably amplified by a number of other flagellates (Swezy, 1916) which show greater or less complexity in their motor apparatus. For the ciliates, however, no such assemblage lias yet been made, although this large field would seem only to await further investigation. Numerous forms of this elass have long been known to possess intraeytoplasmie struetures associated with their motor organelles, but the morphologieal relationship of these structures has been eompletely worked out in only two organisms. 
Sharp (1914) was the first to suceed in this endeavor. Working upon a parasitic ciliate, Diplodinium ecaudatum, common in the stomach of the $\mathrm{ox}$, this investigator discovered a system of fibrils eonnecting all the motor organelles of the oral region. Owing to the shape, position, relations, and staining properties of this system. Dr. Sharp regarded it as having an unnsual signifieance.

The organism in sevelal respects is one of the most complex among all known l'rotozoa. The body, which resembles "a short, plump banana," bears all the organs of locomotion and food-taking at the anterior end. This region is more or less flexible and decidedly eontractile. while the remaining portion of the body is rigid. free from appendages and, for the most part, firmly supported by an exoskeleton. At the anterior extrenity, toward the ventral sicle of the body, is loeated the eytostome. This is an elliptical aperture surrounded bv an oval disk that bears on its inner border a eirclet of oral eilia. 'The cytostome opens directly into the oesophagus, a short tube which ends blindly beside the anterior end of the macronucleus. Around the outer border of the oral disk appears a row of heavy adoral membranclles that function ehiefly in locomotion. Fncireling these menbranelles are an inner and an outer adoral lip dorsal to which lies a prominent opereulum. The latter strueture is eontinued dorsally into the dorsal disk which is surrounded by the dorsal membranelles. These, like the adoral membranelles, are loeomotor organelles.

The relution of the above struetures has been very briefly stated only to facilitate a review of the excellent deseription Dr. Sharp has given of the complex motor apparatus found in this ciliate. The eonstituent parts of this incehanism embrace (1) a motorium lying deep in the ectoplasm beneath the operculum, (2) a dorsal motor strand, (3) a ventral motor strand, (4) a dorsal lip strand, (5) opercular fibers, (6) oesophageal fibers, and (7) a eireumoesopluageal ring. The relation of these parts to the organelles with which they are assoeiated is best deseribed in Dr. Sharp's own words. In a speeimen stained with his modification of Mallory's connective tissue stain, the so-called motorium was first observed as a mass "which had stained rather intensely and showed by transmitted light the same bright red color which was noted in the ease of the mieronueleus. Further inrestigation along this line revealed the fact that not only was this mass constant but (1) that it was connected dorsally, by means of a delicate strand, i.e., dorsal motor strand, with the bases of the dorsal membranelles. also a branch strand ran along the base of the inner dorsal 
lip, i.c., the dorsal lip strand; (2) that a fine strand, the ventral motor strand, ran from it to the bases of the adoral membranelles, also that a branch strand left this ventral motor strand and passed along the base of the inner adoral lip, the adoral lip strand, and that many welldefined fibers passed from it, following the contour of the opereulum toward the right to beeome lost in the immeliate vieinity of the base of the right skeletal structure. These are the opereular fibers. Most interesting of all, however, was the apparently perfectly definite connection with a ring of the substance surrounding the oesophagus at just about the level of the outer adoral furrow. This ring, whieh is designated as the circumoesophageal, as wcll as all of the fibers described as leaving the motorium, showed in all regions the same bright red color. Other fibers also staining bright red are found in the oesophageal walls. These are found in the ocsopliageal walls. These are called the oesophageal fibers, but thus far it has not been definitcly decided whether they take their origin from the motorium or directly from the cireumoesophageal ring, probably the latter, however" (Sharp, 1914, p. 83).

Inasmueh as this complex syistem of motor mass and strands is intimately assoeiated with the motor organelles, one is justified here, as in the ease of the flagellates, in regarding these structures as a part of the animal's motor meehanism, whatever thcir specific rôle may be. But just what is their specific funetion? Three possibilities were obvious: (1) this intraeytoplasmie system may be skeletal, for support; (2) it may be musenlar, the strands representing primitive contractile fibrils; or (3) these strands may have eonductive properties with the motorium functioning as a coördinating center for impulses passing over the primitive neural fibrils. After weighing the evidenec which his investigations had disclosed, Sharp concluded that the last hypothesis was in nearest agrecment with the faets.

The skeletal hypothesis, adopted by Braune (1913) for a similar system found in Ophryoscolex purkynjei of the same fanily as Diplodinium ecaudatum, was belicved by Sharp to be insufficient for his species. The diminutive size of the "motor mass," its nonconformity in shape to the partienlar region of its location, and the want of attachment of the several strands to any fixed struetures were conditions unfavorable to such an interpretation.

Nor did it secm probable that the mechanism is contractile in function. If it were so, it should appear attaehed to fixed structures, on the one hand, in order to affect movable structures, on the other, 
which is not the anse. Forthemore. the organelles with which the strands are associated are nerer translated in "the direction of the strands leaving the motorium. but rather in a direction at right angles to the course of the fibers, thus militating arainst a contractile funetion for the fibers" (Sliarp. 1914, p. s6).

The perfect coürdination in the aetivity of mobile parts, all of which are supplied by strands from the ecntrally plaeed motorium. and the advantageous location of the system to function "as a center of motor eoördination in an animal which is exceelingly active, exceedingly responsive to external stimuli and one, moreover, which exhibits a high degree of seleetive feeding," are phenonena which conld be most satisfactorily explained on the hypothesis that this apparatus funetions as a primitive type of neprous system whose coörclination is effeeted through the eentral motor mass, the motorium. Aecordingly, Sharp gave to this system the name "neuromotor apparatus."

In a fresh-water eiliate. Euplotes palella, a fibrillar system comparable with that of Diplodinium cenulalum lias reeently been worked ont and deseribed by Yocom (1918). It is noteworthy that these two forms are of different orders and habitats as well, the latter an Oligotriclan parasite common in the stomach of rumiuants, while the former is free-living and a member of the order Iypotricha. The presenee of these homologous systems in ciliates so varied in mocle of life and kinship indieates the possible widespread ocenrrence of comparable systems in numerous other forms of this exceedingly interesting and important group of protozoans.

Let us now consider the nature of this "neuromotor apparatus" in Euplotes palclla, as found and described by Dr. Yocom. Prefacing this consileration, it will be convenient to offer a very brief aecount of the extermal form of the animal and the relative positions of its eetoplasmie organelles. The hody in general contour roughly resembles the bowl of a tablespoon, the eonvex surface of which represents the lorsal side of the organism, and the coneave surface its ventral side. For the anterior end, to complete the figure, one shonld pieture a mere stuh of a very broad handle still attached and well rouncled to suit the eontonr of the bowl. The stub would then represent the oral lip of the animal. This lip forms an anterior projection of the clorsal side over a wide triangular eytostome at whose posterior apex is the pharynx situated on the left about halfway down the boly. A series of membranelles borders the dorso-posterior nargin of the oral lip and on the left turns ventrad to continue along the left side of the eytostome into 
the plarymx. The remaining external organelles embrace eighteen styliform eirri. Of these, four are eauclal and fourteen ventral in position. The right anterior ventral surface bears nine eirri, of which six are termed frontal and three ventral eirri. 'The remaining five of those ventral in position, known as anal eirri, are the largest and longest and are the most important. These have their origin at the ends of the five ventral grooves about twenty-five mierons from the posterior end, and extend baekward beyond the eaudal margin of the body.

All the cirri were olserved by Yocom, in agreement with Maupas (1883) and Griffin (1910), to be composed of eilia with distinet basal gramules. The eomponent eilia are imbedded in a dense plate of eetoplasm just beneath the pelliele, the plate serving as a firm support for the cirrus. Now from the basal plate of each anal eirrus there extends a fibel toward the anterior end. These fibers were first seen and figured by Maupas (1883) who briefly deseribed them as joining the five anal eirri and extending forward to converge and unite into a single tliread which disappeared near the anterior end of the animal. In 1903 Prowazek found similar fibers in Euplotes harpa and Griffin (1910) deseribed such fibers for $E$. woresteri. Yoeom, lowever, was able to trace the fibers in $E$. patclla farthen forward to where they join one end of a very small bilobed body, "the motorinm." "It was first seen as a dark body in animaIs stained with iron-alum haematin, lying close to the right anterior eorner of the triangular eytostome. In speeimens which are well destained this body is seen to be composed of very fine gramules elosely grouped together, but if too dark it has the appearance of an almost homogeneous body. Wlen stained with Mallory's stain the motorium beeomes bright red from the aeid fuehsin and laeks the granular appearance charaeteristic of speeimens colored with haematin. Plate 14, figure 5 (mot.) shows that this motor mass does not have a smooth contour, but rather that it has ragged edges with processes extending out into the surrounding setoplasm" (Yocom, 1918, p. 355). The motorium is about eight $\mathrm{I}$ serons long and, as figured, about one-fourth as wide as it is long. Joinjng its left end are the five long fibers from the anal eirri. These fibers, converge and appear to unite with the motorium as a single strand.

From the right end of the motorium another fiber, the anterior eytostomal fiber, was found to pass anteriorly and to the left along tlie proximal border of the oral lip and the bases of the membranelles throughout the entire series. Within the oral lip was observed" a 
conspicnous "lattice-work structure" whose bases, like those of the membranelles, very elosely approximate the eytostomal fiber. Thus is formed (Yocom, 1918) "an unbroken fibrillar complex between the heary anal eirri which are used chiefly in locomotion and the membranelles of the adoral zone which function as organs of food getting. organs of locomotion, and as tactile structures." Several finer and slorter fibers pass out from the base of each of the other thirteen eirri but Yocom foumd no indieation that these fibers connect with any part of the complex uniting the membranelles, the lattice-work structure of the oral lip, and the anal eirri.

The anatomical continuity of this fibrillar system, its selective staining properties, the anterior, free position of the motorium and the intinacy of its several branehes with the large, vigorous anal cirri. with the peculiar diffused lattice-work of the oral lip and with the ever active membranelles, these were significant features which strongly suggested that the whole, unique arrangement must have a function more highly specialized than merely that of support ol even one of contractility. Rather, the system here, as the one in Diplodinium ecaudatum, should be regarded as possessing properties of conductivity functioniug to coördinate the movements of the organs with which it is associated. It, aceordengly, was also designated "neuromotor apparatus."

The morphological evidences which Yocom's researches have yielded lend strong support to this "neuromotor" hypothesis. Yet, however signifieant may be the foregoing evidences favoring the function of conductivity for this novel apparatus in Euplotes, to establish this or any interpretation of organic function, methods beyond the bounds of morphologieal inquiry must be introduced. In this endeavor, the investigator enters another field of lahor, viz., that of experimental biology, the need and importance of which has, in comparatively reeent years, become more fully recognized among biologists. Phenomena studied and deseritud by the morphologists are of primary importance. A comprehensive w owledge of a structure and its relations is prerequisite to an understanding of its function. But functions ean not be ascertained by exploring and mapping parts. Experimental means must also be provided, otherwise further progress is impeded and may even be rendered impossible.

In view of this and because of the important signifieance that attends the theory of the presence in certain Protozoa of struetures which are neural in function, it was thought advisable to undertake the task of which this paper is an account. 
During the winter of 1916-17 when Dr. Yoeom had found and was studying the fibrillar system in Euplotes patella, it secmed to me that the experimental metlod of microdissection might be suceessfully employed to aid in determining the actual function of this system and that Yocom's excellent morphological studies might be supplemented by experimental evidence.

The value and necessity of experimentation was duly recognized by Dr. Yocom, who has already added several experiments of another sort to this essential phase of the problem. "In studying Euplotes patella" (Yocom, 1918, p. 363) "that have been treated with very" weak solntions of certain alemicals, such as nentral red, nuethylene blue and especially nicotine, it has been noticed that the anal cirri and cytostomal membranelles are the last to cease moving. The other cirri become quict but the membranclles and anal cirri have been secn to move even after the cytoplasm has begun to break up. Such plienomena favor very strongly the iclea that the motorium scrves as a coördinating center between the anal cirri and the cytostomal membranelles. However, other observations on living animals grive even stronger evidence in favor of the neural function. It has also becu noted in speeimens subjected to a very weak solution of nieotine that the frontal, ventral and marginal cirri continne noving cven after the animal has ceased to swim about. The menbranelles also nove but more slowly than in normal animals. Oecasionally one or more of the anal eirri may be seen to make a feeble movement not sufficiently strong to canse the animal to move. However, as the animal revives from the effeets of the nareotie and begins to swim about by vigorous kieks of the anal eirri, a decided increase in the rate of movement of the membranelles may be noticed.",

\section{ACKNOWLEDGMENTS}

This experimental investigation has been made under the very lelpful dircetion of Professor Charles A. Kofoid, whose kindly and stimulating eriticisms have eontributed much to any merits the results may possess.

My thanks are also due to Professor S. S. Maxwell for several valuable suggestions on methods and useful literature. 


\section{METHOD AND MATERIAL}

The method of microdissection has been greatly improved with the use of glass needles manipulated in a three-movement holder introduced several years ago by Dr. M. A. Barber and later extensively employed by Kite and Chambers (1912), Kite (1913a and $b$ ), Chambers $(1914,1915,1917 a, b$, and 1918) and Seifriz (1918). The technique used by these investigators makes possible the dissection and observation of ova, spermatozoa, fresh tissues and Protozoa under the highest magnification of the microscope. A detailed description of the method is given by Barber (1914) which has been elaborated by Chambers $(1915,1918)$. I have made use of the principal features of this method in these studies on Euplotes patella.

The efficiency of the Barber instrument is indeed remarkable. Considerable experience was found necessary for drawing the finer and most serviceable needles, but their manipulation in the three-movement holder is a comparatively simple matter. One learns the adjustment of the screws controlling the needle almost as readily as the operation of a mechanical stage. After some practice the facility with which the apparatus may be manipulated and the feats thus made possible with a glass needle are rather surprising.

Moist chambers.-Two forms of moist chambers have been successfully employed. A Bausch and Lomb monocular microscope having a rotary stage was first used. For this stage a convenient round moist chamber was devised as follows: The base of a heavy, extremely shallow petri dish, in diameter slightly less than that of the rotary stage, was fastened upon the latter by means of two brass posts $20 \mathrm{~mm}$. long screwed into the elip holes of the stage. The upper ends of these posts firmly supported the top of a large stender dish, this top or roof having a diameter equal to that of the bottom or floor. It will be observed that both roof and floor were thus securely fastened to the rotary stage. On the other hand, the wall of the moist chamber, made from the upper portion of the stender dish mentioned above, was solidly attached by two brass arms to the shank of the microseope and was of such height as to permit free movement of the roof and floor. A hole through the wall on the right allows the insertion of the needle into the moist chamber. Also, a circular hole $20 \mathrm{~mm}$. in diameter 
appears in the center of both the roof and the floor. Inside the chamber around the lower hole was sealed a glass ring which completed a sliallow enclosure for water or moist cotton. A heavy steel shank supported the Barber holder. The shank was elamped to a metal base upon which the mieroscope also was fastened. This sort of moist chamber on a rotary stage has one advantage of much importance for the microdissection of Protozoa: while the animal is being held by water-glass surface tension it may be rotated and so ent through any part at any desired angle.

The other moist chamber, constructed on a plan very similar to those described by Barber (1914) and Chambers (1915, 1918), was used with a mechanical stage on a Bausch and Lomb binocular microscope. The mechanical stage was reversed and fitted onto the left side of the microscope stage, the Barber instrument being attached to the right side. The combined use of the mechanical stage aud the Barber holder is often advantageous and sometimes necessary. This arrangement just stated, which allows the frec use of both hands, has been found very convenient. For a detailed deseription of the rectangular type of moist chamber, the articles of Barber (1914) and Chambers (1915, 1918) may be consulted, and further account of it here is unnecessary.

Binocular microscope.- Most of these experiments have been performed with the ajd of a binocular (Bausch and Lomb) microscope. Especially for microdissection purposes, this instrument is much superior to the monocular microscope. To ohserve clearly the position and adjustments of the necdle in the vertical dimension was found to be very essential in several experiments. As will be described later, all the anal cirri were successfully removed from a few animals without any apparent injury to the body. This, it scems, would have been impossible with only monocular vision. Furthermore, the general contour of the organism, the relative positions and movements of its organelles, the cyclosis of the granules of the endoplasm, the contractions of its vacuole and its forms of behavior in ereeping and swimming are much more satisfactorily studied under the binocular microscope. The use of both eyes soon becomes fully as desirable in microseopieal as it is in unaided vision.

Glass needles.-Much of one's success or failure in microdissection can be attributed to the quality, shape and size of the needles employed. Soft glass needles are of little value in making incisions, but because of their flexibility they may be used to hold the protozoan withont 
undue pressure and without injury in order to study the movements of organelles and cyclosis phenomena. Needles made of Jena glass were found to be very suitable for general purposes and especially useful in performing transections and the excision of parts. But even more serviceable were the needles drawn from a hard quality of Pyrex and glass tubing. A special mixture of this glass may be obtained from the Corning Glass Co., Corning. N. Y. This is less flexible than the Jena glass and apparently not as fragile. For making narrow incisions and the excision of organelles, quartz needles are quite
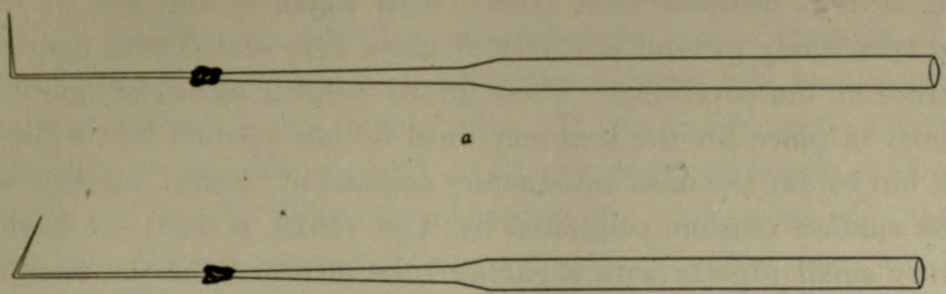

$b$

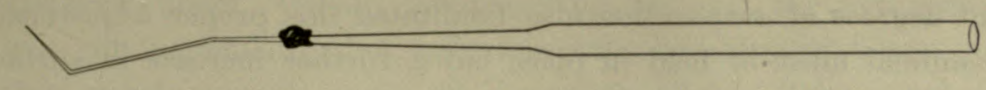

$c$

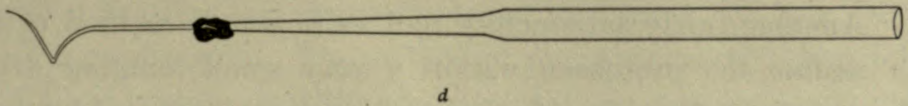

Fig. A. Types of glass needles used in microdissection.

superior in every respect. The costliness of this material becomes negligible if the needles are drawn from tubing that is about one half the diameter of a pin, then sealed with "orange stick" in a handle made of ordinary glass tubing. In fact, I have come to use this method also in making needles of Jena and Pyrex glass. These were drawn in a very small alcohol flame, but an oxygen-gas or oxy-acetylene flame is necessary for making quartz needles. The finest points were obtained by completing the needle not in but quite near the flame. Muscular sense is more dependable than eyesight for drawing very fine points, some of which, especially those of quartz, are less than a micron in diameter. The shape of what may be called the shank of the needle was found to be of considerable importance. The figures 
above (p. 415) illustrate four forms of shanks which were found most serviceable. For eonvenience I have named these: $a$, right angled; $b$, acute angled; $c$, obtuse angled, and $d, V$-shaped shanks. Needles a and $b$ have been used for probing or tearing regions or dissecting off parts; needles $c$ and $d$ for making incisions and, particularly $d$, for bisecting the organism, making wide ineisions or snipping off organelles. The V-shaped shank affords more flexibility, which may be inereased by lengthening the $Y$.

Control.-To provide for the control of the organism during operation, several methods were tried. Fine fibers of silk and of cotton, also very finely ground particles of glass were sealed with agar to the surface of the cover-slip. These afford helpful means of loolding the animal in place for the beginner until he has learned the rather difficult hut by far the most satisfactory methor of eontrol, namely. waterglass surface tension, suggested by Kite (1913, p. 146). I have used a very small pipette with a rubber tube attached for the mouth as a means of transferring the animals and reducing the volume of the hanging drop to afford just the necessary amount of surface tension. This amount one learns only after eonsiderable practice. Allowing slight degrees of evaporation also facilitated this proper adjustment. The animal must be held in place but a further inerease in surface tension may eause it to disintegrate, often with explosive violence. A perfeetly elean surface of the cover-slip and a wide hanging drop, say $10 \mathrm{~mm}$. in diameter, aid greatly in obtaining proper surface tension. Another fairly satisfactory and more simple method of control is to confine the protozoan within a very small hanging drop. the surface tension of which with the glass is greatly redueed by applying a mere trace of paraffin or some other liarmless oil.

In making an incision, the needle was applied suddenly and rather firmly by means of the up-and-down movement screw. After an interval of a few seeonds, this screw was slowly turned back and forth, which caused a seesaw movement of the needle-point. With proper care and if the needle be not too flexible, a surprisingly elean cut may thus be made without any loss of endoplasm. Chambers (1917a) has very helpfully suggested the use of a needle not exceedingly fine and the importance of slow movement and sufficient time in making an incision. Otherwise a loss of endoplasm usually results and this may be followed by rapid and complete disintegration. This outflow of endoplasm may, however, be regulated to advantage by applying a $V$-shaped needle near an animal in which a careful incision has been 
made and which is held near the edge of a wide but very slanllow hamging (lrop. By slowly turning the serew for the up-and-down movement. delieate changes in the degree of stress of the surface film are thus effected. an outtlow of endoplasm may be inclueed and jts rate of discharge varied more or less at will. As will later be deseribed. this affords a study of several interesting features including the nature and extent of the ectoplasm and of the pelliele.

Staining.-Several vital stains lave be'n employed with varying suceess. For the study of the extermal organelles, a .0001 per eent solution of hacmatoxylin gave the most satisfying results. 'This was also useful in staining the fibrillar system; restain new features of this system, in fact. were first sem after the animals had been subjeeted for about eighteen lours to this stain. It was ineidentally diseovered that a very weak solution (.001-.0001 per eent) of tannie aeid, after eight to ten hours, distinetly sharpens the outline of the fibrillar apparatus. This is apparently due rather to its effect upon the eytoplasm, affording a contrast which discloses more clearly the apparatus. Neutral red (Gribler), new metlyylene blue R (C. C. Co.), toluidin blue (Grübler) are among other vital dyes which enhaneed the view of the system of fibers. Usually for dissecting. however, the anal eirri fibers and not infrequently the motorium with its attached fibers, may be seen elearly enough under oil immersion (2 mm. Zeiss apochromat), withont the aid of intra vitum dyes.

For studying specimens fixed and stained before or after dissection, the several fixatives and stains employed lyy Yoeom (1918, p. 342) were used with gool results. The method of picromereuric fixation followed with Mallory's stain or with iron-haematoxylin was especially valuable, for the study of the fibers before and after they were ent. Delafield's haematoxylin stains the fibrillar apparatus even more distinetly. There was some evidence that the ent fibers do not stain so deeply with the iron-haematoxylin. bit this lias not, as yet, been definitely ascertained. Much eare is neeessary in staining single specimens. Fixatives were applied, usually hot, by means of the pipette (above referred to) under the low power binocular. The speeimen was then transferred to a cover-slip or slide which had been treated with Meyers albumen fixative. After a distinet film had formed, the slide was passed through the aleobols and stains, usually without detaehment and loss of the specimen.

Material.-The fresh water eiliate, Euplotes patella, possesses certain morphological features that make it an unusually choice subject 
for microdissection studies. Plate 29, fig. 1, illustrates several structures which are very favorahle for operative work on the nenronotor apparatus. The large C-shaped nueleus permits the cutting of the anal cirri at several points with no injury to the mucleus. Also, the cytostomal fiber may be eut at various angles and the motorium destroyed likewise witlout injuring the nucleus. The stiff, fairly tough pellicle which envelops the body ably maintains the normal form after an incision, often very deep, has been made. The remarkable firmness of this strueture makes possible the removal of eirri with no apparent injury to the body. The projection of the oral lip and of several cirri affords successful excision of these parts, and the definite grouping of the frontal, ventral, anal, and marginal cirri permits various transections and combinations of transections and exeisions that have proven to be exceedingly useful in studying the functions of these groups of organelles in creeping and swimming movements. The location of the single micronucleus at the anterior end of the body is especially favorable for ascertaining more aceuratcly the specific rôle of this interesting and important organ.

\section{THE LIVING ORGANISMI}

Owing to the invalnable aid of water-glass surface tension for the control of Protozoa in a hanging drop, it is now possible to study active, living organisms in minute detail under the highest magnification. With a properly construeted moist chamber, the time limit for this study depends rather upon the endurance of the observer. A living Euplotes was held continuously within the ficld of a $2 \mathrm{~mm}$. Zeiss apochromat lens for more than two hours, at the end of which time. when a drop of water was added, the animal swam slowly about; within half an hour its movements were apparently normal. This allotment of time is ample for a complete, detailed review of all the structures and movements of the organism that may appear within the range of microscopical vision. By properly adjusted, transmitted light. the binocular mieroseope witl an apoch romat lens affords here the view of a living, active form that rivals any of nature's finest displays. The study of living organisms always lends increased interest and adds the essential complement to our knowledge of the structures and relations disclosed in fixed material. 


\section{ENDOPLASM}

In his microdissection studies on living ora of eertain marine invertebrates. Chambers (1917a) finds their eytoplasm to eonsist of "a lỵaline fluid matrix in whieh are imbedded granules of various sizes." The granules, classified into mierosomes and maerosomes, differ consiclerably not only in size but also in number, shape, solnbility. refractive indices and in elemical reactions. Rapid tearing of the intermal cytoplasm with the needle inclueed in that region the dissolution of the macrosones and liquefaction of the eytoplasm in which the mierosomes exlibited distinct Brownian movements. Such injuries sometimes spread throughout the entire cell. Also, a rapid dissolntion of the maerosomes oeeurred with the ontflow of the eytoplasm into the sen-water "if no protective membrane intervened." The mierosomes were much more resistant and displayed the dancing Brownian movement for a considerable time after the complete disappearance of the licuefied eytoplasm. A protective membrane frecuently formed around a mechanically injured. disorganized area within the cell or on the surface of endoplasm exuding through a rupture of the surface-film or ectoplasm. This nembrane is directly comparable with the ectoplasm. Both represent a colloidal gel enelosing the endoplasm which usually exists in the sol state but may come to form temporary organs such as the cell asters (Chambers, 1917b) by a reversal of the sol to the gel state.

A similar consistency of eytoplasm ean be identified in Euplotes patclla. Here, however, the general appearance of the endoplasm is considerably modified by food racnoles which are of various sizes and sometimes numerous. But with ligh magnification and well-regnlated light, hosts of small gramules, comparable with Chamber's microsomes, appear througliont the entire body. Larger granules or macrosomes are less conspicuous and have been observed only in the endoplasm. Both the large and small granules are larger than the macrosomes and microsomes deseribed by Clambers. The small granules are fairly constant in size, with a diameter of about one micron or more. Here and there within the endoplasm they exhibit Brownian movement. They appear round and are highly refraetive. The large granules vary from three to five mierons in diameter, are usually opaque and often irregular in shape. They have not been identified in the ectoplasm and never appear within the eyelosis eurrents of the endoplasin. Mechanical 
injury by rapid movements of the needle-point causes their disappearanee in that region of the body. They may be observed for a time within small globules of the endoplasm which have flowed out along the sides of the needle and become enveloped with a "protective membrane." But if the outflow of the endoplasm is sufficiently rapid and of such quantity as to prevent the formation of a membrane, these large granules quiekly swell and burst or otherwise disappear, and the lyaline, liquefied endoplasin disappears leaving only the small granules, which may remain for hours constantly in Brownian movement. In one instance this lancing movement of the gramules continued throughout part of an afternoon and evening, a period of about six hours.

\section{ECTOPLASM}

The outflow of endoplasm and disintegration of the organism from ineisions made abruptly or from other eauses is generally rapid and sometimes explosive. To prevent this sudden disruption and regulate the rate of outflow of endoplasm, a metlod which has been previously deseribed (p. 416) was used. This method permits a careful study of the ectoplasm and pelliele. The ectoplasm eonsists of a comparatively thin, gel matrix with densely paeked small granules of a dimension similar to that of the smaller gramules of the endoplasm. These ectoplasmic granules appear equally numerous throughout, closely approximating the pellicle on one side and the endoplasm on the other. Griffin (1910a) describes similar granules in the ectoplasm of $E$. ureesteri which, however, vary in size and appearance more than do these granules.

Frequently, there is evident a fairly definite boundary between the ecto- and endoplasm but this condition apparently varies. If its outflow be not too rapid, the endoplasm separates from the eetoplasm and pelliele, sometimes leaving large areas that may remain intact for several seconds. With further disintegration of such areas, the pelliele and matrix of the ectoplasm quiekly disappear, but the granules here, like the "mierosomes" of the endoplasm, may persist for several hours in eontinuous Brownian movement. Plate 33, fig. 23, shows a.portion of ectoplasm with a frontal cirrus attached. The position of granules on one side illustrates the manner of disintegration.

A further discussion of the pellicle appears under the caption "Experimental.", 


\section{Macronucleus}

The outline and structure of the large C-shaped macronucleus appears in the living, unstained organism very much as in the fixed material figured and described by Yocom (1918). The "contraction phase" of this organ with its reconstruction bands may be clearly observed in animals free-from too many food vacuoles. But these features and particularly the granular, mesh-work consistency of the macronucleus ean be much more satisfactorily studied after the latter has been dissected out with the needle. It is then found to be a highly

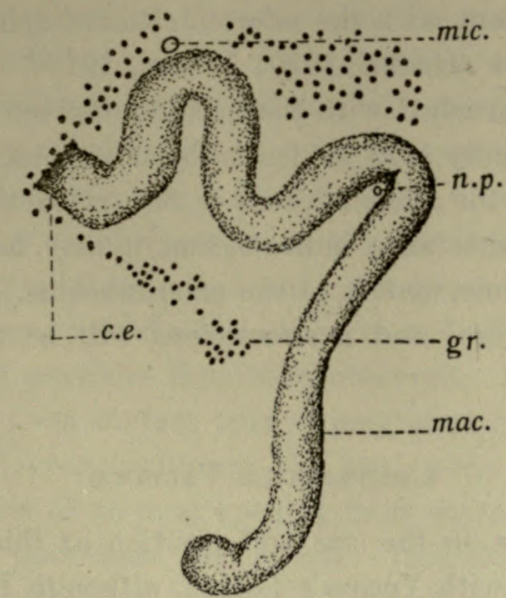

Fig. B. The nuclei of Euplotes. c.e., eut end; gr., ectoplasmie granules; mac., macronueleus; mic., micronucleus; n.p., needle point.

gelatinous, rather rigid structure composed of small granules imbedded in a viscous, hyaline matrix (text fig. B). The organ is enveloped by a very thin, structureless membrane. Upon exposure to the water, the macronucleus increases slowly in size; within half an hour or so small blisters of the membrane slowly appear over the surface; the rate and extent of swelling increases and, upon rupture of the membrane in one or several places, there follows a rapid dissolution of all except the small granules, which for several hours exhibit a dancing Brownian movement. These granules vary somewhat in size, with an average diameter about one fourth that of the microsomes found in the endoplasm. 


\section{MicronuCleus}

This organelle is much less conspicuous than other organs in living, nnstained animals, but when once clearly identified it may always be readily loeated with suitable magnification and properly regulated light. The variations in position and size depending upon its several phases (Yocom, 1918) have bcen defintiely verified even withont the aid of vital dyes. With a .0001 per cent aqueous solution of neutral red, haematoxylin, methylene blue or Bismarek brown, both mieroand macronucleus become sharply outlined and the visibility of their structure is considelably enhanced. Several times the macronucleus has been dissected ont with the micronucleus attached and lying in a very shallow pocket (Griffin, 1910; Yoeom, 1918). In two cases, the micronucleus was brushed with the needle-point out of the depression in which it was feebly held evidently by a viscous, ductile substance that stretched only for a few microns in fine, retractile threads. These properties of this substance indicate that it may be comparable with the hyaline, gelatinous matrix of the macronucleus. Other interesting features of the micro- and macronucleus will be treated in a later paper.

\section{CONTRACTILE VACUOLE}

My observations on the size and position of this organelle are in general agreement with Yocom's (1918), although I have observed an abnormal increase in its size after certain vital stains such as neutral red, Bismarck brown, Congo red, gentian violet, fuchsin $\mathrm{S}$. ete., have been added to the water. Moreover, any distinet mechanieal disturbanee, e.g., rapid movement of the needle to and fro through the hanging drop, continually jarring or shaking the moist chamber, etc.. effeets very noticeable changes in the size and period of pulsation of the vacuole. One should then expect, as is the ease. that incisions, transections, or exeisions would similarly affect this organelle. It would appear, indeed, that the contractile vacnole in Euplotes patella is exceedingly sensitive to various stimuli. The average size of this vacuole in ten carefully handled animals was 29 microns at maximum diastole. Its diameter upon disturbance or after incisions may become 45 or even 50 microns, and its period of pulsation, which is normally about forty seeonds between systoles, may thereupon vary from three to fifteen minutes. 
The discharge of the vacuole is chearly on the ventral side within three or four microns of the right unargin of the pelliele. This may be observed with careful foeusing when small food vaenoles are lying just pasterior to the point of discharge. The relative position of the last trace of a systole, as compared with that of the food partieles and ventral pelliele, appears distinetly ventral. Also. this position may be verified by applying the needle-point very lightly against the ventral surface near the point of diseharge, whereupon the position of the lischarge is ventral.

\section{Anal Aperture}

This has been loeated in E. patella on the ventral side slightly posterior to the diseharge pore of the eontractile vacuole and within five mierons of the margin of the pelliele. It was first observed when two frustules of Navicula were seen to pass suceessively from an animal held in a shallow hanging drop. The emission of various other feeal particles, mostly rery small, has sinee been noted in several individuals. Voiding apparently seldom oeeurs when the stress of surface tension or the pressure of an applied needle is inereased. In only tliree eases has the enission of partieles thus been observed. However, pressure from the needle or from surface tension may sometimes cause the protrusion of a small area ineluding the anal pore. Griffin (1910a) deseribes the location of an anal opening in $E$. worcesteri immediately to the right of the ontermost anal eirrus. This elosely approximates the position of the pore in $E$. patclla. But the pore in $E$. vorcesteri is anterior to the contractile vaenole, whereas in $E$. patclla it is posterior. It shonld be said, however, that the position of the eontractile vacnole varies considerably in different $E$. patella which, of course, somewhat alters the relations above referred to.

\section{Cirri}

The eighteen styliform eirri of Euplotes patella appear on the ventral side in four fairly well defined groups. Yoeom (1918) elassifies these into six frontal eirri, three ventral cirri, five anal and four marginal eirri, which is in agreemnt with Stein (1859). While the groups of frontal and ventral eirri are less elearly defined than are the others, it is at least more eonvenient and, I believe, more aceurate to regard the frontal group as eomposed of seven, and the ventral group of two cirri. Also, for further eonvenience in deseribing the 
microdissection experiments, I should sublivide the seven frontal eirri into an anterior group of three and a more posterior group of four. Aecordingly, these will hereinafter be referred to as the "yroup of three" and the "group of four" frontal eirri.

The eiliary composition of the cirri of various Euplotes is a well established faet. The component eilia with their basal gramules have been deseribed for the cirri of $E$. lanmus by Minkiewiez (1901), of E. harpa by Prowazek (1902), of E. worcesteri by Griffin (1910). and of E. patella by Yocom (1918). This feature of a cirrus may be readily demonstrated in a shallow hanging drop by means of a $\mathrm{V}$ shaped disseetion needle. Here a detached eirrus may be pushed to the edge of the hanging drop for greater surface tension and gently rolled to and fro between the needle and cover-slip. Soon the cirrus splits into loose bundles of its numerous eilia. But this method reveals other features: the eilia are embedded in a gelatinous matrix that is highly viscous, as may be seen by pushing the bundles abont with the needle. These remain attached at one or several plaees even after rather rough handling. They frequently adhere to the needle and so may be pulled a eonsiderable distance through the water. Tpon exposure to the water for a few ininutes, the cilia of the bundles further separate and show adhering to their sides minute globules of the coagulated matrix. The question here arises whether this coagulation of the viseous, hyaline matrix may not account for the extreme rigidity that overtakes the eirrus soon after its detaeliment, when it may be pushed about and even beyond the margin of the shallow hanging drop withont any apparent bending. Furthermore, after examining mumbers of these cirri by the above method, one becomes rather convinced that the matrix-eilia eomplex is invested with an extremely thin, structureless membrane that is fairly tongln but very flexible. I have not been fully satisfied abont this strueture sinee I have not clearly seen it apart from its enelosure. This final evidenee may later appear. However, if present, the membrane rapidly dissolves from a recently detached eirrus, which then splits into its eomponent cilia.

Except the anal eirri, all are round at their base and gently taper to a rather sharp point. The two riglt marginal eirri are fumbriated (Yoeom, 1918). Not infrequently the second and third (numbering from left to right) anal cirri are also fimbriated. The shape of the base of the anal eirri differs considerably from the others. Figures 19 and 18 show the comparative dorso-ventral width and lateral thickness of an anal cirrus base, the former being six to eight microns and the latter about three microns. 
The attaeloment of the eirri will be discussed in connection with a description of the neuromotor apparatus. It remains lere to describe briefly the several movements that ale common to the different groups of rirr. Piitter (1903) discusse's these grenelal types of eiliary movements among l'rotozoa: (1) the "hook-like" type, foumel in eilia or Hagella used for food-taking: (2) the "whip-like" trpe, exemplified by the flagellum of Euglena, and (3) the "infundilunlar or fummellike" type, very (ommon anong most flagellates and eiliates. The anal eirri of $E$. patella frepuently exemplify types both (1) and (2), while trpes (2) and (3) are common for their frontal, ventral. and marginal cirri. Yocom's observation (1918, p. 363), that the anal cirri "move in only one plane. that parallel to the median plane of the body," is hardly adequate. As will be deseribed presently, these cirri are very frequently used in guiding the animal to the right or left, and are especially active as the chief means for making sharp turns to the right, which is not an uneommon reaction during swimming. In the latter instanee, particularly eirri 3,4, and 5 (numbering from left to right) are flexed ratler abruptly near their base and lash elose along the ventral surfaee of the body. Griffin (1910, p. 301) regarded the anal cirri of $E$. uorcesteri to have "only a single, strong motion: a vigorons kick directed baekwards." In $E$. patella, however, this backward stroke is by no means the only effective movement. nor even the Inost important. The "avoiding reaction" of this species, which will be deseribed further on, is effected chiefly by means of the anal eirri. Finthermore, these cirri, togetler with the frontal and ventral groups, are the animal's "feet" for creeping and. as we shall see later, upon removing the anal eirri, ereeping hecomes impossible.

Another eommon use of these amal eirri may be observed in their attnchment to suspended débris in the water and swimming about with it sometimes for several minutes; or, less frequently, in holding on to floating débris or even to the dissectiug needle and suspending the body dorsal sidle down, oceasionally at an angle of fifteen degrees or more. The attachment, to the needle at least, is usually with two or three and often four anal eirri. In such eases I liave observed elearly a slight flexure of the tip of one or mose cirri about the needle and had concluded this to be the means of supporting the body; but later, an attachment by only one cirrus was seen with the tip several mierons in length lying along the under side of the needle. This latter observation las since been made a number of times and in two instances I was able to move the needle slowly back and forth without disturbing 
the animal, when the support was sufficient to earry the body along with the needle. As to how this curious feat may be aceomplished I ean only eonjeeture the possibility of a seeretion present on the eirrus.

\section{MEMBRANELLES}

Projecting anteriorly from along the dorsal base of the oral lip, the series of membranelles turn ventrad on the left in a gracefully twisting eurve and continue along the left side of the eytostome and pharynx to end in a hooklike turn at the apex of the pharynx. Yoeom (1918, p. 4) has aptly likened the twisting and general shape of this eontinuous series to the collar and lapel of a eat. His splendid detailed description may be referred to for the more minnte structure of these organelles. A furtler deseription encerning only their attaehment and their relation to the neuromotor apparatus will be given later nnder the heading "Experimental." However, the considerable disenssion on the actual relations of the cilia which eompose the membranelles deseribed for varions Euplotes is here worthy of note. Obviously, these relations eondition the shape of the membranelles. For E. harpa, Wallengren (1901) describes and figures the membranelles as triangular in shape. Ninkiewiez (1901) found those of E. vannus to be of a similar shape. Yocom's discussion of this point would seem to favor the view of the above anthors, although he does not refer to the particular shape of a membranelle. Griffin (1910a). on the other hand, states that after repeated examination of these structures in $E$. worcestcri, he is inclined to believe that the membranelles which are nearly reetangular in shape are eomposed of distinet eilia "with movements so perfeetly coördinated that they aet and ordinarily appear as a single and delicate band" (p. 299). Möbius (1887) had eome to the same eonehisions regarding both the shape and strueture of the membranelles of $E$. harpa.

From the present studies on E. patella, I am convinced that the cilia composing a membranelle in this speeies are definitely fused and that they are so arranged as to give each membranelle the shape of an elongated triangle. Indeed, those extending over the oral lip (fig. 16) approximate the form of a short cirrus with a very wide base. By means of a disseeting needle, several of those dorsal to the oral lip may be exeised, together with a portion of that organ from which they readily separate, and thus the features mentioned above may be exhibited. They may very soon split into bundles of eomponent cilia 
that show basal granules distinetly, while later there appear along the eilia minute, coagnlated globules comparable with those deseribel for the eirri. Also, exeellent views of the shape and arrangement of the "ntire series of membranelles may be had upon transferring an oryanism to a hanging drop of 0.1 per cent solution of tannie acid. The animal usually dies within a few minutes but in the meantime the membranelles becone stained and their movements are slowed so as to afford a splendid study of eaeh membranelle of the entire series.

The primary funetion of the membranelles of the eytostonal and pharyngeal region is food-taking. Yoeom (1918) has diseussed the manner of the intake of food, but he does not refer to the expulsion of partieles from the pharynx after they lave been "sampled" and refused. This ejection may be sometimes rather violent and is effeeted hy a reversal of the membranelles which may involve only those of the planryx, or also the eytostomal membranelles, or oceasionally even the entire series. The ehief funetion of the adoral membranelles is their indispensable service in swimming. An aconnt of this important feature is given in later paragraphs.

\section{Neuromotor APp.ARATLS}

The system of fibers connecting the series of membranelles, the lattice-work strueture of the oral lip and the five anal eirri to a small bilobed body lying in the extreme anterior right of the animal, together with other fibers radiating from the base of the remaining thirteen cirri were found and deseribed by Yocom (1918) as the neuromotor apparatus of Euplotes patella. In preceding paragraphs I have given a brief but fairly eomplete review of Dr. Yocom's aceount of this apparatus. It is my purpose here to reconsider eertain parts of his aecount and in following paragraphs (see "Experimental") offer a few minor modifieations and additions (fig. 13).

Following Yocom's figures and descriptions, I have been able to identify in the living organism all the structures of this interesting and complex meehanism. The anal eirri fibers are usually distinetly visible throughout most of their length. The presenee of food vacuotes dorsal to the frontal eirri frequently interferes with the traeing of these fibers to their junetion with the motorium, but this interferenee may be obviated by keeping the animals in well-filtered water for several hours, at the end of whieh time most of the food vaeuoles will have disappeared. It is then possible to observe not only all five fibers 
throughont their extent but also the motorium and from its outer end the membranelle fiber passing to the oral lip and membranelles. After they are onee elearly identified witl the aid of vital dyes, the motorinm and its connecting fibers may be recognized usually with little diffieulty in unstained animals.

The several fibers associated with the base of the frontal, ventral, and marginal cirri are much less distinetly visible. Very eareful focussing and regulation of light are necessary, and even then it is usually impossible to make sure of these fibers without the aid of vital dyes. This may be said also of the membranelle fiber along the base of the membranelles. Here the presence of the basal corpuseles of the cilia composing the membranelles and of a compact row of large ectoplasmic granules (fig. 17) renders this fiber so obsenre that a distinet and satisfactory view of it may be luad only after dissecting off the membranelles and oral lip and allowing the eetoplasm to disintegrate. Most of the lattice-work complex within the oral lip may be distinctly seen in ventral view. The basal attachments of this to the membranelle fiber are indistinet if at all visible, due to the basal corpuscles and large granules of the ectoplasm.

\section{Movements}

So far as I have been able to ascertain, the creeping and swimming movements of the genus Euplotes have not been described. In this speeies, Euplotes patella, there are evident three specific creeping and six swimming movements. Of the latter, two are much less common than are the other four.

Being typieally of creeping habit, this animal is usually found moving about on the bottom of an aquarium or over various débris and vegetation or on the under-surface of scum or of the surface film of the water. Its ereeping movements, therefore, are readily observable. This method of locomotion is effeeted by means of all the cirri on the ventral surface, aided more or less by the ever active membranelles. The three kinds of creeping movements are: (1) locomotion straight ahead or slightly to the left (orally), (2) a quick, backward movement, usually for a distance about equivalent to the length of the body, or less, and (3) a turn to the right (aborally) through an angle of thirty to sixty degrees. Movements 2 and 3 are comparable with Jennings' "avoiding reaction." The accomplisliment of movenent 2 probably involves 
all the cirri to some extent but eliefly the anal eirri and adoral membranclles, as experiments later will show. Movement 3 is affected also with the aid of all eirri and aboral membranelles, but chiefly by means of the frontal eirri, exeept when the turn is very rapid and through a large angle, say 90 degrees; then all the eirri, but prineipally the frontal and anal cirri and the adoral membranelles, are brought into play. Crecping is rendered impossible upon excising the anal or the frontal cirri. This feature will be deseribed later under the head "Experimental."

Euplotes patella's swimming habits are less common than are its (ereeping movements but the animal ntilizes this speeial advantage by no means infrequently. Also, the variety of its swimming movements indieates considerable profieiency in this valuable mode of locomotion. The six movements in swimming, above referred to, are as follows: (1) straight ahead without rotation, (2) straight ahead in spiral rotation. (3) eirens movement to the right, without rotation, (4) cireus movenent to the left, without rotation, (5) a sharp turn to the right, similar to ereeping movement (3), and (6) movement direetly backwards, comparable with ereeping movement (2).

It will be convenient here to recall the spceial, effective strokes of the membranclles and of the various groups of eirri: $(a)$ The effeetive strokes of the membranelles may pull the animal forward or by reversal drive it backward. Withont the interplay of eirri, the tendency of direction by means of the membrancles is neither straight ahead nor straight backwards but in a eireuit, as will be shown later. (b) The candal cirri may funetion as rudders or as propellers. The two on the right usually function as propellers; the two on the left, as rudders. Griffin (1910), for the caudal cirri in E. worcesteri, finds the tendencies of their movement to be just the reverse of those which I lave aseribed to corresponding eirri in E. patclla. (c) The anal cirri may lash directly backward, individually or simultaneoisly, and so drive the animal forwards; or they may lash directly forward, not always but often synehronously, driving the animal backwards; or they may lash to the right side with the effective stroke backwards or forwards, thus aiding to turn the animal to the left or right respectively. (d) The frontal and ventral cirri commonly show infundibular movement. with the effective stroke directed variously; only oceasionally has the lashing. whiplike movenent been observed in these cirri.

(1) The "straight ahead" swimming movement is of short duration. but oceurs rather frequently, particularly after the animal has been 
strongly stimulated mechanically, e.g., by stirring the water violently. This movement is often observed upon transferring an animal to the hanging (lrop by means of a eapillary pipette. The anal and marginal eirri may aid in this movement but they are not essential. (Experimental evidenee will be given for this and following positive statements.)

(2) Spiral movement is the one most frequently observed. For this movement, the marginal cirri are not essential, the anal cirri are useful and the froutal cirri very valuable. Without the adoral membranelles the movement normally is quite impossible.

(3) Cireus movement to the right is frequently seen after the animal has been eonfined in a narrow hanging drop which may be either comparatively deep or shallow. The anal and marginal cirri may aid in this movement but they are quite unessential. The frontal eirri, partieularly the "group of three" are useful here but the movement is performed ehiefly by means of the adoral membranelles.

(4) Cireus movement to the left is so infrequent that the means for its aecomplishment have not been studied. It has been observed only when the animal was confined in a hanging drop.

(5) The sharp turn to the right is performed ehiefly by means of the adoral membranelles and anal cirri. The marginal cirri are here useful but not essential. The movement is very common. Usually the spiral movement does not proeed far without this sharp turn intervening to divert the animal's course.

(6) The backward movement is effected ehiefly also by the anal eirri and aluays eoneomitantly with the reversal of the membranelles. It is wholly an avoiding reaction and is distinctly eomparable with the ereeping movement 2 . Indeed, it may be regarded as merely the augmentation of that movement 2 , as shown by disturbing the creeping animal sufficiently with the needle-point or by applying some ehemieal. such as methylene blue. The animal may thereupon dasl baekwards a distance several times its length, even repeating the movement again and again. In this respect $E$. patella strongly reminds one of its relative, Uronychia, whose avoiding reaction brings into play the large posterior eirri which are seldom if ever otherwise used (Calkins, 1911, p. 98). 


\section{EXPERIMENTAL}

The following results are from experiments macle on several hundred Euplotes patella. Of these experiments, 315 were recorded with fairly extensive notes on the exact loeation and nature of the ent and on the animal's reaetions before, during, and after the operation. allowing several minutes for its recovery from the shock effects. The various ents inelude: (1) transections (diviling the animal in any plane at right angles to its long axis), (2) excisions of external organelles with or withont a portion of the body, and (3) incisions in the body or oral lip in any plane. Efforts were made also to ascertain some of the physical properties of the pelliele and of the fibrillar system.

\section{Peidicle}

This membrane which completely envelops the body and oral lip of Euplotes patclla is firm, fairly tough, and suffieiently rigid to maintain eonstantly the normal form of the body and lip, even when the animal is subjected to a considerable stress from elianges in water-glass surface tension or to the applied pressure of a fiexible needle. Figure 1 shows the extent of an incision fully two-thircls the widtl of the body, yet this animal continnally kept its normal shape during a half-hour of devious movements throngh the water. In making disseetions the toughness of the pellicle requires the use of needles with rather stiff, short points. Long-pointed, very flexible needles are ineffective.

The extensile property of the pellicle is quite obvious in an animal which has gorged itself with food until the body is conspicuously bulged. If such an animal be subjected to a gradually inereasing pressure by the surface tension method previously deseribed, just sufficient to cause the egestion of a few food particles through the pharynx. then as the needle is slowly removed the pellicle may here and there beeome wavy or wrinkled. Within a few minutes the wrinkles usually entirely disappear. The elasticity of the membrane may be readily demonstrated by applying a fairly flexible needle the full width of the body when, with due pressure there oceurs a conspicnous bending of the body over the needle. Upon releasing the pressure the body at once resumes its normal shape. This may be repeated suceessively many times. If, however, the animal has been 
well flattened out by surface tension for about an hour, the flatness persists for a time after a drop of water has been added, but gradually the body recovers its normal form, usually within half an hour or less. During an incision, short furrows frequently appear on either side of the ncedle (fig.1). These may remain for some time but eventually disappear.

Any apparent modification in the shape of Euplotes patella occurs only from extrancous pressure: That the animal of itself is unable to vary its sliape may be observed when it is hemmed in by eotton or silk fibers partially sealed to the cover-slip. Paramecia in the same hanging drop force their way among the fibers through narrow passes with constrictions of the body, a feat quite impossible to $E$. patella. Further contrast in the pellieles of these two forms is seen upon adding a weak solution (.1 per cent) of tannic or acctic acid. "Blisters" quickly appear on Paramecium but not on $E$. patella, although both may die in the solution within a few minutes.

\section{FibrilianR Sístem}

Studies of the fibers and their relations were made by means of various dissections but the most satisfaetory observations were had when a slow disintegration of the body was brought about by inducing delicate changes of surface tension with a V-shaped needle. Thereupon the fibrillar system and its attached organelles would often remain intact and were always the last part of the body to undergo disintegration.

The anal cirri fibers normally lie upon the inner surfaee of the ectoplasm just above ventral grooves which are formed by clearly defined ridges. Each ridge is ehiefly composed of a single row of very large ectoplasmic granules (fig. 20) that at times present internally a finely granular appearance and often persist several minutes after the body has entirely disintegrated. Sometimes they have been seen to swell and burst explosively, disappearing entirely from view. These and surrounding smaller cetoplasmic granules lie embedded in a hyaline, gel matrix which apparently is continuous with the basal plates of the anal eirri. This region of ectoplasm resists disruption longer than the adjacent portions and so it frequently happens that the anal cirri fibers, which lie upon the inner surface of the ectoplasm, all remain intact after the eomplete disintegration of the body. This condition, however, does not long prevail. Soon the ectoplasm here 
shows sigus of dissohtion by a gradual dispersion of its granules and the anal eirri fibers, with or without their eirri attached, are at length set free, their spatial relations occasionally remaining unehanged. Careful ohservations during this tardy disintegration of ectoplasm, alnng with the explorations by means of the needle, make it fairly eertain that the anal eirri fibers do not lie within the ectoplasm but npon its imer surface, being supported there by a very thim. hyaloplasmic sheath which may be a eontinuation of or eomparable with the hyaloplasmic matrix in which are embedded the gramles of the ectoplasm. The eritical foeus for a fiber does not appeal to be identieal with that for the ectoplasmie gramules along (below) the fiber. Furthermore, the fibers are more or less readily displaced by means of the needle, although when undisturbed they remain adherent to the eetoplasm.

When set free from all attaehments, the anal eirri fibers may be bent variously with the needle (fig. 15). They are then found to be fairly flexible, in no wise brittle and almost wholly irresilient. However, before the ectoplasm has eompletely dissolved. the fibers are much less flexible and generally reever after being bent. Figures 14 and 15 illustrate several permanent shapes into which the fibers were bent by means of the needle. They may adhere to the needle and so be pulled about through the water. They do not long resist dissolution and so disappear usually within fifteen mimtes or less time after their exposure to the water.

Apposed dorsally to the basal plate of each anal eirrus, the corresponding fiber is modified into a "fan shaped structure' (Yocom, 1918) which I shall here designate the "anal fiber plate." This small plate is distinetly rectangular (fig. 14), and not oval as figured by Yoeom. Its attachment to the fiber proper is seenre, as may be readily ascertained by pulling or pushing the fiber about through the water with the needle-point. An interesting and signifieant feature is its intimate association with the basal plate of the anal eirrus. Figure 14 is a eamera drawing of a eirrus in the proeess of detachment from the "anal fiber plate." It will be observed that the eirrus has rotated 90 degrees on its long axis and that the gelatinous extensile basal plate. which is a highly viseous gel, remains attached to the anal fiber plate. This attached condition is rarely found, owing to the readiness with which the basal plate detaches from the anal fiber plate. While attempting to make this drawing with the parts in situ, the separation ensued so readily that I sueceeded in outlining only the partial detachment as shown in the figure. 
Just as the anal eirri with their attaehed fibers frequently persist intact after the remaining eytoplasm has dissolved, so also do the membranelles with the membranelle fiber resist immediate disintegration. Furthermore, in seven reeorded instances I have observed the anal eirri, their fibers, the motorium, the membranelle fiber, and the membranelles, all remain united for several seconds to about three minutes after the disruption of the body. In three of these eases, the anal eirri and inembranelles continued lashing, but feebly and for a few seconds only.

The motorium with its attached membranelle and anal eirri fibers has been distinctly identified after more or less complete disintegration of the body. Mueh more frequently, however, only the fibers are evident. It would appear, therefore, that the motorium readily detaches itself from its comnceted fibers or otherwise vanishes, perhaps by rapid dissolution. In its normal position the motorium may be readily displaeed with the needle-point. IIowever, it resmmes its usual position upon the removal of the needle. Jut if it be pushed too far. say ten mierons, out of place it may become detached from its fibers, or apparently injured to such an extent tlat it dissolves or otherwise disappears.

In unstained animals, as stated previously, the membranelle fiber may be distinctly seen only a short way from its attaelıment to the motorium. Thereafter it beeomes coneealed among the ectoplasmic granules along the basal plates of the nembranelles (fig. 17). It may be observed only after these granules have dispersed with the dissolution of the eetoplasm. Its general physieal properties are apparently the same as those above stated for the anal cirri fibers. That deseription may suffice for this fiber also.

However, associated with the membranelle fiber and membranelles, certain plates have been found which I shall here call the "membranelle fiber plates" (fig. 13). These were first clearly observed upon partial disintegration of the series of membranelles whieh had been disseeted from an animal vitally stained for about eighteen hours in a .0001 per cent aqueous solution of haemotoxylin. The nembranelles proper had been set free, thus exposing these plates, one for eaeh double row of membranelles. Figure 17 is a camera drawing of the plates and the membranelle fiber. The spokelike formation shown in the figure is usually assumed by the series of plates upon detachment of the membranelles and disintegration of the ectoplasm. This arrangement is clearly oceasioned by their individual attaehment at 
only one end to the membranelle fiber. Explorations with the needle show this connection to be fairly seeure. Also, the relation of each membranelle to its corresponding membranelle fiber plate las beun found to he the same as the relation of the anal cirrus to its anal fiber plate. Of this one may be fully convineed upon olsserving the mentbranclle peel from its plate, a process which oeenrs not infrequently. ahout one minute after the disruption of the ectoplasm. Thereupou. the bisal plate of the membranelle, in which the basal corpuseles of the enmponent cilia and the eiliary rootlets are imbedded, completely separates from the membranelle fiber plate which. like the anal cirrus plate, shows a smonth, clean surface, with no evidence of any eiliary rontlets laving been attached.

'The "dissociated fibers" deseribed by Yocom (1918) as radiating at the base of each of the thirteen eirri (i.e., exchding the anal cirri), have been foumd to be definitely commected witl a plate somewluat sinilar to the anal cirri plate, although of a shape (fig. 21) eorresponding to that of the hase of the eirrus. These were first observed upon the disintegration of an animal likewise stained with a .0001 per eent aquenous solution of haematoxylin. Several radiating fibers were distinctly seen to be mited to each plate. As yet, I have not definitely olservel the separation of one of these plates from its cirrus. Indications in two eases where the separation was almost complete point towarl a relation between cirrus and plate here that is similar to the relation of an anal fiber plate to its corresponding cirrus. I shall designate these plates the "clissociated fibers plates." Figures 21 and 21 a show several such plates from the same organism which vary slightly in size and shape. These variations are apparently common.

\section{Tr.iNSECTIONS}

Between the "group of three" and "group of four" frontal cirri (fig. 2).-The auterior part of the animal swims rapidly (ef. swimming movement 3, p. 429), the inner side, that with the three froutal eirri, performing a small eirele and the opposite side a colrespondingly larger one. This performance contiuues the same after more water is added to the hanging drop. The part infrequently revolves, as on the long axis of the normal animal, and it oceasionally reverses the effective stroke of the membranelles to drive itself a short distanee backwards (ef. swimming movement 6, p. 429). In either case the cirens movement to the right is soon resumed and continues with few sueh interruptions until the part apparently becomes fatigued and dies. Deatl 
generally results within an lour after the transection, but in three cases this ceaseless activity eontinued for more than four hours. Any indieations of regeneration have not been observed.

The posterior piece is much less active. It usually swims straight ahead and oceasionally in cirenits to the right (ef. swimming movements 1 and 3, p. 428) and very frequently revolves, then with obvious diffieulty, on the long axis. It remains most of the time inactive, seldom ereeps and always very slowly and feebly, and responds more or less readily to jarring or to stimuli effeeted by the needle-point. In the latter ease its anterior end is very little if any more sensitive than other parts of the body. A distinct avoiding reaction (ef. swimming movement 6 , and ereeping movement $2, \mathrm{p} .428$ ) has at no time been observed. Use of the frontal and marginal eirri is eonspieuously more normal than is its use of the anal cirri, espeeially when attempting to creep, as on the under surface of the inverted cover-slip.

Experiment 106 (fig. 2).-Anterior piece swims very rapidly in right circus movement with the three frontal cirri as a "moving center." Occasionally it whirls and tumbles deviously about; it may then swim straight ahead revolving two or three turns on its long axis, but very soon returns to cireus movements. It very seldom reverses the effective stroke of membrancles, even when needle is thrust in its way. Frontal cirri beat continually as also do the membranelles.

Posterior part mostly at rest with occasional movements of frontal and marginal eirri less often of the anal cirri, except when another $E$. patella runs into it; then it dashes for a short distance usually straight ahead. It then bumps into piece of debris which it pushes straight ahead but does not go far. Jarring starts its movements, which soon cease. Anal cirri are commonly moved upon any lashing of the other eirri which is sufficient to nove the body. It would appear that they initiate such movement, which is then taken up by the anal eirri. When stimulated with a needle point, its anterior end is little if any more sensitive than are the sides or postcrior end.

Transection just posterior to the "group of four" frontal cirri (fig. 3).-Anterior part swims in eircus movements, although somewhat less completely than does the anterior piece above deseribed. It resorts more frequently to rotation on the long axis and to the reversal of the organelles to drive the part backwards, although here, too, the "rotation" movement is more common than the reversal reaction. The part never creeps but swims rapidly and eontinuously for hours after the operation. It does not turn slarply to the right (cf. swimming movement 5, p. 429) and very seldom shows the avoiding reaction upon being stimulated by the needle. After several hours the part may come to rest on débris, on the surface film of the water or on the eoverglass. It is then generally very sensitive to slight jarring or other mechanical stimuli, whereupon its rapid swimming may be resumed 
for long periods. Its oral lip is more sensitive to a stimulus by the neelle-point than are the membranelles over the oral lip, or its posterior, ent surface, or the frontal eirri or any other part.

The posterior part is generally rery much less active. Howerer, in ten reeorded instances this piece revolved on its eut surface as an axis exeeedingly rapidly (about two revolutions per second) for a half minute or less just after the transection was completed. This revolving performance, generally at a much slower rate, is a common reaction of the posterior piee following this operation. The direction of these revolutions is clockwise when viewed from the left side. For some time after the ent is made the anal cilri are quite active with their effeetive stroke in such a way as ehiefly to indnee the revohutions. This part swims in eirens movements to the right infrequently and very sellom rotates on the long axis; when it does so, it moves quite clumsily and imperfectly. Within about an hour movement eeases. It is then much less respousive to mechanical stimuli than is the anterior part, after eoming to rest. When thus stimulated its movements, which are for the most part revolntions, are effected chiefly by means of the two ventral and the two right, fimbriated marginal eirri, the anal eirri remaining more or less passive.

Experiment 209 (fig. 3).-Anterior jart swims violently in various devious movements, sometimes rotating on the long axis or reversing to swim a short distance baekwards, but most of time it moves in right circus movements. This ceaseless swimming eontinued from $11: 50$ A.M. until about 5 P.M., when its movements were considerably slower, and at 5:30 P.M. the part was resting on débris. Readily responded to touch of the needle point against the oral lip, but less so when the adoral membranelles, frontal cirri or posterior eut surface was similarly stinulated. Slight jarring induced violent swimming, which lasted about thirty seconds, after which it again became quiet. At this time rotation on the long axis was nore common than previously. Following morning, this part had died.

Posterior part not very aetive from the first. Anal eirri beat slowly, irregularly and witl little effectiveness. Oecasionally swam in eircus movement to the right and sometimes slowed imperfect rotations on the long axis, but more often its novements were revolutions about the eut surface as an axis. Within forty minutes, it had become passive, the two right marginal eirri infrequently showing movements which were always infundibular but witlout effect. Only slightly responsive to jarring, then generally revolved as before but very few times, after which it again beeame quite inaetive. These revolutions were effected malnly by the two right, fimbriated marginal eirri with infundibular movement; the two on the left lashed with the effective stroke upward, thus indueing the revolutions. The two ventral eirri were active most of the time, also showing conspieuously the infundibular type of movement. The anal eirri, on the other hand, were mostly inaetive; irregularly one or two might lash feebly, but never more than one at a time. Their effective stroke was always backward, therefore tending to aid the part in its rotations clockwise as viewed from the left. This part also died within about thirty-six hours. 
Between the two ventral and five anal cirri (fig. 4).-Here, the movements of the anterior piece are quite similar to those of the same part described just previously. There is, however, less tendency to swim in eircuits to the right and spiral swimming movements are considerably more frequent. Indeed, in the two respeets just mentioned, this part elosely approximated the eorresponding swimming movements of the normal animal. There are, on the other liand, some notable differences: (1) Aroiding reactions (swimming movement 6, p. 429) are seldom observed even when the oral lip region is strongly stimulated by means of the needle, or when some disagreeable solution, such as methylene blue, is introduced. (2) Creeping is very infrequently attempted and is conspieuously more or less impossible. In a few cases, the piece has been observed to crawl slowly and awkwardly for a short distance over-débris or along the needle. but this ability is distinctly inpaired. (3) Sharp turns to the right liave not been seen. Tortwous, random movements that involve turning both to the right and to the left are sometimes resorted to but these are reaclily distinguishable from the short, sharp turns to the right which are common for the normal animal (swimming movement 5, p. 429). (4) The creeping "avoiding reaction" (number 2, p. 429) has at no time been observed even when mechanical stimuli are applied.

The principal eharacteristic movenıent of this posterior piece is its rotating on the cut surface as an axis, a rotation which is not uncommonly very rapid (two or three times per seeond) following the completion of a transection. This performance is of brief duration and the piece comes to rest on the surface film of the hanging drop or upon débris. Thereafter, it is nisually very irresponsive to mechanical or ehemical stimuli. If aroused. jts revolving movements are performed chiefly by means of the marginal cirri. the anal cirri functioning individually and spasmodically, or not at all. But previously, just. after the operation. the anal cirri were very active and mostly responsible for the rapid revolutions. Imperfect eircus movements to the right and aboral spiral movements are quite uneommon for this part. These have never bcen observed after the marginal eirri were excised, as a later experiment will show.

Experiment 160 (fig. 4).-Anterior piece immediately swims in cireus morements to right, but as often or more of ten moves in aboral spiral straight aliead. Sometimes performs winding, devious movements but returns to spiral swimming or to circus movements. During ten minutcs it reversed three times to swim a short distance backwards; this reaction fairly normal. Two hours later, resting on débris. Very responsive to jar, also to needle. Oral lip much more sensitive than membranelles, cirri, or any part of the body. Slowly and awkwardly 
erawls a short distance over débris. Does not show ereeping "avoiding reation" when stimulated with needle point or by means of methylene blue. Also, applied weak acetic acid, when part swam straight forwarl, then reversed the effective stroke of organelles, swimming backwaris a short distance, but agrain swam in eireuit or in spiral apparently beyond the influence of the acia solution.

Posterior part turned over and over very rapidly, two times per seconl, with cut surface as axis. This continued about twelve minutes. Slowed and came to rest on surface film of hanging drop. Ialf lour later, very irresponsive to jarring or needle-point. Aroused anil for few seends revolved as before, but very slowly ant chiefly by means of the marginal eirri. Anal cirri mostly passive or indivilually and irregularly aetive. Again eame to rest. From jarring, slowly moved in eireuit, very awkwardly, hy irregular pushing of one or two anal cirri; other anal cirri were passive.

\section{Excisions}

Rcmoval of oral lip with adoral mombranclles. Anterior piece always shows one and only one reaction, viz., cirens movement to the right. This movement is very rapid and continues until the part becomes fatigued and dies, which generally occurs within fifteen minutes or less after the excision. The effective stroke of the membranelles is the same here as when the normal animal swims in a circuit or spirally straight ahead. In many specimens observed, there was at no time any indication of the reversal of membranelles, and the path of the cireuit was continuonsly abont the same. This part did not possess the motorium.

The reactions of the posterior part are mostly very similar to those described for the same part when a transection was made between the "group of three" and "group of four" frontal cirri. In the former. lowever there are present the "group of three" frontal cirri and the motorium. This piece is able to creep fairly normally and in a few instances gave the creeping "avoiding reaction," although the anterior end here was mneh less sensitive than the oral lip of a normal form. Swimming is uncommon and abnormal. Spiral rotations on the long axis are infrequent and quite imperfect. The part more frequently revolves with the cut surface as an axis, but this movement is generally combined with a sort of spiral movement on the long axis. Of five such posterior parts carefully observed, one regenerated an oral lip after budding off about twenty microns of its anterior end; the bud, containing three frontal cirri, was more or less spherical, quite active for about an hour, but died some time during the night. The other four of these five regenerated normally but only after eighteen to thirty hours. 
Removal of marginal cirri-These, due to their exposed position, were readily snipped off with the needle. The excised parts thereafter were never observed to beat. But when one, two, three or all were removed with some of the body plasm the cirri continued lashing very rapidly and driving the pieee deviously through the water until death, whieh followed a few minutes later. When an exeision (properly, a transection) of the eaudal end was made to inelude all four marginal cirri, the piece revolved very rapidly with the cut surface as an axis but in such manner as to move speedily through the water with the left side foremost. Such removal or the snipping off of some or all of these cirri did not apparently modify the several swimming or ereeping movements of the normal animal. If, however, these eirri had been removed from an animal whiel was then transected just anterior to the anal eirri, the posterior part usually rotated rapidly, the cut surface as its axis, for several minutes. Cireus or spiral movements were at no time observed. But within an hour after becoming quiet it was irresponsive to mechanical stimuli and did not resort to rotating movenents again. The anal cirri lashed feebly, very irregularly and ineffeetively.

Excision of frontal cirri.-Owing to the length of these eirri and the extension of four of them beyond the right lateral margin of the body the four may be snipped off with a $\mathrm{V}$-shaped needle. Thereafter, the animal very seldom attempts ereeping and its spiral movements are abnormal. In the latter instance, its anterior end rotates in a larger spiral than that of the posterior end. In two eases al] but one frontal cirrus were either snipped off or removed by inserting the needle-point at the base of each eirrus, thus to gouge them loose. These cirri came off rather readily. Three of them beat several times following their detachment. In eaeh case the animal could not ereep, but frequently swam slowly in eireuits, or in spiral movements with the anterior end deseribing spirals which were about twiee the dianeter of those of the posterior end. No discernible injury resulted from gouging out these eirri; the movements of both the membranelles and anal cirri were apparently normal. In a few instanees, the animal gave the avoiding reaction upon stimulation of the oral lip with the needle-point, although these were feeble and abnormal. However, both animals died within forty-eight hours without regenerating new frontal cirri. Their deatl may have been due direetly to injuries from the exeisions or indirectly to infections or other eauses.

Excision of anal cirri.-Infrequently, E. patella were found with fully half of the anal cirri extending beyond the eaudal unargin of the 
body. In several eases the anal eirri, to about two-thirds of their length, the marginal cirri and a suall pieee of the eamdal end of the body were exeised. Creeping was thus male practically impossible, the animals resorted more frequently to cireus movements to the right, and slarp turns to the right were not evident. Spiral revolntion on the long axis was apparently normal. Four such auimals regenerated the excised parts, ineluding the anal eirri.

Several attempts were made to gonge off the anal eirri just as the froutal eirri lad been removed. In two experiments (nos 215 and 216) all the anal cirri were suecessfully lemoved, with little or no injury to the body. In each ease, there followed several signifieant results: (1) the animal was unable to creep, (2) it did not turn sharply to the right. (3) the avoiding reation was never observed, and (4) eireus movements to the right were performed more frequently.

Experiment 216.- Removed anal (irri 4 and 5 (see p. 424). Released the animal by adling water to the hanging drop. It then performed all the major swimming and ereeping movements, ineluding the avoiding reaction.

Again drew off the water and removed the remaining anal eirri. Upon adding more water the animal was olservel to revolve in spirals on the long axis and to swim in cireuits to the right, but at no time was it seen either to ereep, to turn sharply to the right, or to give the avoiding reaction. Its efforts to ereep on the under side of the cover-glass were unsuceessful, the posterior end being suspeniled so as to incline the bolly at an angle of about 30 degrees with the eover-slip.

\section{INCISIONS}

Through the oral lip without cutting the cytostomal fiber.-There was no apparent deerease in the sensitivity of any part of the oral lip. and no ehange in the normal movements and funetioning of the adoral membranelles. The results were wholly negative. The eut usually healed completely within an hour.

Through the oral lip, severing the cytostomal fiber (fig. 5).- - Ir, seventeen eases there resulted abnormal swimming movements and distinet elianges in the movements of the membranelles on either side of the ineision: (1) the progress of the animal forward was impeded, (2) in its spiral revolutions, commonly the anterior end deseribed a wide spiral, (3) eireus movements to the right were markedly less common as was also (4) the oceurrence of the avoiding reaction, and (5) periods of quiet were more frequent and of mueh longer duration. Upon examining with high power the movements of the membranelles, a difference in rhythm was frequently eonspieuous between the series on the left side of the ent and those on the right side. The former 
were always active with that effective stroke which normally tends to drive the animal forward. The membranelles on the right side of the cut oceasionally moved in eoördination with the former or sometimes did not move in the least but projected straight out from their bases. Not infrequently, they were distinetly seen to beat with the effective stroke in the opposite direction to that of the series on the left side of the eut. Carmine granules or india ink which had heen introduced into the water clearly indicated these three changes in the behavior of the adoral membranelles on the right side of the eut. It will be noted that the membranelle fiber at the base of these membranelles on the right side of the incision was continuous and in connection with the motorium. These results of sucl experiments were very obvious and remarkably uniform.

Incision through the membranelle fiber at any point posterior to the oral lip (fig. 6).-Differences between the rhythm and direction of the effective stroke of the membranelles anterior to the incision and of those posterior were apparently identical with those just deseribed above. However, the swimming movements following such incisions were practically normal. Some animals (three especially were noted) were less active after the incision and slowed more tendency toward circus movements; otherwise, their swimming and ereeping reactions were comparatively normal.

Incisions on the right or left side or at the posterior end did not sever the cytostomal fiber or any of the anal cirri fibers.-Following such incisions made in many animals at various angles through the macronueleus or not (figs. 10-12) I have never as yet observed any noteworthy change in their normal swimming or ereeping reactions or in the perfect coördination between the series of membranelles and the anal eirri.

Incisions severing all the anal cirri fibers.-Ineisions were made (1) on the right side between the group of three and the group of four frontal cirri (fig. 7 ); (2) on the right side between the group of four frontal cirri and the two ventral cirri (fig. 8); and (3) on the right side between the two ventral eirri and the five anal cirri (fig. 9).

After severing the anal cirri fibers at any one of these three regions, two significant ehanges were evident in ereeping and three in swimming movements: (1) there was distinctly less tendency to ereep; the animal when not swimming was more frequently found quiet on the surface of the eover-slip, on the surface film of the hanging drop or upon débris. But when ereeping, the anal cirri were used with less sureness and facility than normally. That much was eommonly evident 
upon careful observation. Nevertheless, the lack of coördinated movement between the frontal and ventral and the anal eirri (these being the animal 's creeping feet), was mot at all times conspieuous. In some eases (four recorded instanees), this coördination was apparently about normal. Even here, lowever, it was obvious that the frontal eirri sometimes initiated the movement which was then taken up by the anal cirri, but this suecession was not always evident; (2) the avoiding reaction was very seldom observed. If the oral lip were touehed by the needle-point (a stimnlus which normally induces the avoiding reaction) the incised animal would infrequently give this reaction, but more often would turn to the right anteriorly (ef. third ereeping movenent, p. 428), thus avoiding the stimulus without performing the preliminary backward movement (ef. second ereeping movement, p. 428). The three notable changes in swimming movements after the ineision were: (1) A tendency to swim in eireuits to the right. This reaction was particularly noticeable just after the incision was eompleted, when it became for a time the only swimming movement. The tendeney, nevertheless, persisted even until the wound was more or less fully healed. (2) Sharp turns to the right were quite infrequent and in a few eases were at no time observed (three of these were recorded). This movement is effected chiefly by a strong, quiek lash of the outermost three or all five anal eirri. The performance of this stroke is possible for these anal cirri after the fibers are eut, as will later be shown, but apparently such strokes are not readily or simultaneously linked up with eorresponding beats of the membranelles; (3) The backward swimming movement (number 6, p. 429) has not been definitely observed, as yet, in any of these ineised animals, even when stimulated mechanically by means of the needle or chemically with such reagents as methylene blue or aeid solutions. In one instance, this or a similar reaction was apparent, but of this I could not make certain. It oecurred upon adding a solution of methylene blue with a needle pipette. The movement baekward was only a short distance, two or three times the animal's length; this was followed by rapid eireus movements to the right and was not repeated, as is usually the ease with a normal $E$. patella.

Cutting the anal cirri fibers or the membranclle fiber or both near the notorium, or destroying the motorium.-The general effects upon swimming or creeping movements were definite, fairly constant, and mueh the same after performing any of these ineisions. These movements have, in faet, already been deseribed in the foregoing paragraph. It is important, therefore, to note that the destruction of the motorium 
by means of the needle-point produees modifications in the animal's severaI movements which, so far as I have yet been able to ascertain, do not differ inarkedly from the effects that follow severing the membranelle fiber or the anal eirri fibers or both near the motorium, or the anal cirri fibers at any point. There is, then, no certain evidence from these experiments that the funetion of the motorium is more specific than that of its attached fibers. These negative results may be attributable, however, to faulty or insuffieient technique. On the other hand, the differenees in the behavior of the membranelles on the left and right sides of the incision severing the nembranelle fiber; which were previously deseribed, might indieate there some rôle peenliar to the motorium.

Perhaps the elearest evidence for the want of coördination and of coneomitancy of movements between the membranelles and anal eirri appeared in these incised animals upon supporting one of them against the under surface of the eover-glass with a very flexible needle. To the hanging drop had been added a trace of india ink or a carmine solution; thereupon, any ehanges in the direction of the effeetive stroke either of the anal cirri or of the membranelles were quite eouspieuous in the corresponding movements of the particles of india ink or of carmine. Infrequently the carmine granules were driven in the same direction by the membranelles and by the anal cirri, and the effective stroke of these organelles varied symelnonously. This eoncomitancy however, did not long continue. Their phases of rhythm. it would seem, changed so that now while the membranelles were driving some particles anteriorly, other particles were being driven posteriorly by the anal cirri, or vice versa. These changes were conspicuous and frequent.

\section{DISCUSSION}

These experimental studies have yielded some evidenees on the nature of organelle movement in Euplotes patella which are here wortlyy of consideration. The significance of the general problem of eiliary stmeture and movement, probably due to the prevalence of eilia in both protistan and metazoan organisms, was early recognized (Stuart, 1867) and has oeeasioned the writing of a large literature. most of which lias been reviewed by Pütter (1903), Prenant (1914). and Saguchi (1917). Aside from minor modifieations, the strueture of cilia, wherever found, appears mueh the same. A eilinm is composed 
of two different parts (Anicr. 1903), an clastic axial filument covered by a sheatl which. accorching to Khainsky (1910), is contimnous with the pellicle. Fach cilium arises from a basal gramule situated in the eetoplasm beneath the pelliele (Piitter, 1904). The theory of Henueguy and lenlossek, that this grammle in metazoan cells is a derivative of the centriole, has recently been opposed by Sagneli (1917), who regarels the gramules as having their origin in nitochomlria. Continued from each loasal gramule into the cell-plasm is a fibril, the ciliary rootlet, which in certain ciliates lins been found to mite with other sucl rootlets by means of a basal fibril ruming parallel to the periphery beneath each row of cilia (Maier, 1903). In flagellates, the basal gramule or blepharoplast may show two sureh rootlets, one uniting the blepharoplast to the nucleus and the other comnecting the blepharoplast and parabasal body (Swezy, 1916).

The component cilia of the eirri and membranelles in Euplotes patclla clearly possess each a basal gramule and ciliary rootlet (fig. 17). As previously stated, the granules and rootlets lie within the basal plate of each cirrus and membranelle, which in turn is united to the eorresponding fiber plate. There is, as yet. no evidenee that the ciliary rootlets are united to the fiber plate and they are here regarded only as contiguous with that plate. The ease with which the basal plate detaches from the fiber plate and the want of indications on its surface that there were ciliary attachments favor this interpretation.

As regard the movement of cilia. there appears in the literature a enusicleable difference of opinion as to how this movement is produced. Certain investigators regard the cilium as wholly passive, its movement being effected either by way of the basal granule (Henneguy, 1898; Lenhossek, 1898; Peter, 1899; Joseph. 1903; Saguchi. 1917), or by the contractility of the ciliary rootlets (Simroth, 1876; Benda, 1899). There are others who believe the cilimm itself to be aetive (Engelmann, 1879; Klebs, 1881; Bütschli, 1885; Schilling, 1891; Fischer. 1894; Kölsch, 1902 ; Prowazek. 1903; Pütter. 1903; Gurwitz, 1904; Erlard, 1910; Kolačev. 1910). Its power of contractility lies either in the axial filament or in the protoplasmic sheath surronnding the filament.

Favoring the latter view are the observations of several anthors who have noted that cilia may continue to contract after they have become detached. Klebs (1881) saw in the long flagella of Trachelomonas that contractions and extensions contimed after the flagella were detached from the body. Biitschli (1885) describes movements 
of a detached flagellum of Glenodinium cinetum, which rolled up in corkscrew fashion, remained quiet for a moment, then straightened out and soon turned over in an up-and-down movement. These movements lasted for only a minute or less, after which the detached flagellum came to rest and did not move again. Schilling (1891) observed similar reactions in detached flagella of Peridinium and Fischer (1894) saw that the detached flagellum of Polytoma continued its movements for some time after it had separated from the body. In an isolated cilium of Phycomyceten zoospores, Rothert (1894) clearly observed several movements. Kölsch (1902) saw cilia on a blister of paramecium that continued to beat rapidly. He thought that to these cilia the basal corpuscles remained attaehed. In detached cirri of Euplotes harpa, Prowazek (1900) observed repeated movements.

It is not uncommon, during the disintegration of the body of $E$. patella, to see frontal or marginal cirri continue several contractions upon being set free. Occasionally, but less frequently, I have distinctly observed detached anal eirri to show similar movements. Sometimes the movements of detached frontal cirri, even after being gouged out by the needle, were quite vigorous, and continued so for several seconds. As formerly stated, frontal and marginal cirri have been suipped off with a V-shaped needle. In very few cases was it possible to cut these cirri off and carefuly observe any reactions of the excised parts. However, such parts were never seen to contract. Their faihure to show any movement may have been due to injury which resulted in rapid death. Anyhow, from the various ways in which the cirri of this animal are used, not only in creeping and swimming but also in attachment to objects, which in several instances were observed to involve distinct flexures (as over the needle or about pieces of débris) it would seem that contractility inheres throughout the cirrus.

Furthermore, rather more frequently, the movements of the membranelles may be distinctly seen to continue after separation from a disintegrating body, even for longer periods than those of detached cirri. As few as four membranelles have been cut off which afterwards showed several fairly normal movements. Attempts to excise a single membranelle and observe any contractions were unsuccessful, but the failure would appear to be due rather to inferior technique.

It is obvious that the contractions of anal, frontal or marginal cirri or of membranelles of $E$. patella are not conditional upon attachment to the body and, therefore, not upon any mechanism within the body. 
Another matter of consiclerable importance here coneerus any specifie function which a group of orgunelles in $E$. patclla may perform. Are there indications of a division of labor among the several groups of cirri and membranelles? Since in many ciliates the body is definitely differentiated and frequently bears several sorts of organelles, sueh as cilia, cirri, membranclles, etc., some authors have regarded this differentiation in the form and position of organelles as representing a division of labor among the several groups. Pearl (1900) conchded from observations on Colpidium that the effective stroke of a group of anterior cilia, which is always toward the oral side when the animal is stimulated by the elcetrie eurrent, caused the borly to turn toward the aboral side. Similarly, Puitter (1900) observed that the peristomial cilia in Stylonychia, with their effective stroke toward the oral side, produced the swerving of the body toward the aboral side.

If these usual morements are effected wholly by a special group of organelles, then the movenients should disappear upon the removal of those structures. Accordingly, Jennings and Jamieson (1902) undertook to ascertain the effeet of the remioval of one or more groups of organelles in Stylonychia, Stentor, Spirostomum, and Paramoecium. These investigators found that when any of these ciliates were cut into pieces, "if they are not too minute or too irregular in form, the pieces swim in a spiral, swerving continually toward a certain side, just as do the entire organisms" (p. 232). It became evident, therefore, that the usual reactions of these animals could not be attributed to any partieular set of structures, but that all the organelles have a share in the production of these charaeteristic movements.

The several transections made on $E$. patella indieated a similar tendency in the movements of each of the two picees. Here, however, the reactions were not so definite or so invariable as were those for eiliates deseribed by Jennings and Jamieson (1902). It will be recalled that the swimming movements of $E$. patella are more varied than are those described for the above animals. In addition to the spiral swimming movement which is, indeed, very common in this ciliate, at least five other characteristic swimming movements have been identified, three of which - the circus movement to the right, a sharp turn to the right, and the backward, avoiding reaction-are by no means uncommon. Furthermore, the transections have shown that the anterior piece possessing only the group of three frontal cirri and adoral membranelles swam almost eonstantly in circuits to the right, 
although the piece reverted oceasionally to the spiral movement and to the backward, avoiding reaction. Now, since the excised oral lip reaets only in right circus movements, it would appear evident that these organelles are chiefly responsible for the same movements when only the three frontal cirri are added. And one may enquire whether the circus movements to the right by the normal animal may not be effected mainly by these adoral membranelles. The fact that when such movements are performed the anal and marginal cirri not infrequently remain wholly passive, and that these movements are more common after the anal and marginal cirri have been removed, would lend support to such a conclusion.

It was also observed that a sharp turn to the right was accompanied, if not mainly produced, by the quick lateral flexure of the anal cirri, and that when these eirri were removed, this reaction was never distinetly observed.

Again, the usual reaction of the posterior part resulting from a transection just anterior to the anal cirri, was a rotation with the cut surface as an axis. Circus movemens to the right were infrequent and still less frequent were the spiral, revolving movements on the long axis. In faet, neither of these two movements was seen if the marginal eirri had been snipped off previous to the transeetions.

From these observations, therefore, it appears that in $E$. patella one of the several swimming movements prevails in a piece formed by a transeetion, or that one of these movenents becomes less frequent and may not appear at all upon the removal of a group of organelles, suel as the anal cirri.

These facts, nevertheless, are not contradictory to the more general, truth, viz., that all the locomotor organelles eoöperate in the performance of any eharaeteristic movement. The very signifieance of organization precludes any other interpretation. But are we to regard each group of organelles equally effective in producing any one of these movements? If so, then the removal of the marginal cirri should impair a given movement in the same manner and to the same extent as excision of the adoral membranelles impairs that movement. But it can be said with certainty tlat the same results in each case do not follow. Were we to assume that all the locomotor organelles of $E$. patella function to the same end with equal effeetiveness, it would be necessary to regard both the adoral membranelles and the marginal cirri as distinctly ereeping organs, which they are not. In this respeet, therefore, we may speak of a division of labor among the locomotor organs of $E$. patella. 
None would question the evidence for a division of labor annong the intracytoplasmic organclles in this eiliate, and the several experiments previously deseribed would indicate that the extracytoplasmie organelles, also, may share a degree of speeifie, but none the less coördinated, functions in the animal's norual belavior. Accordingly, in accomplishing such swimming movements as the sharp turn to the right or the quick backward, avoiding reaction, we may regard the anal eirri as especially effective if not normally indispensable, much as the large cauclal cirri in Uronychia are largely responsible for that animal's very rapid, backward movements (Calkins, 1911, p. 98).

In this consideration, it is important to note that the feature of eördinated aetivity is in all respeets evident in the normal $\boldsymbol{E}$. patella. The elaim here made is that the perfection of both creeping and swimming movements is dependent upon the eoöperation partieularly of those organelles (e.g.. the frontal and anal cirri in ereeping) whieh eontribute most effectively to the performanee of any usual movement. Therefore, the elimination of any important group of organelles, or the interference with any mechanism by whiel they operate or eoöperate with another similarly important group, should result in pereeptible changes in swimming or in creeping movements.

We may now enquire: Does the fibrillar system in Euplotes patella represent a mechanism that affects the external organelles individually? Or does this complex, unified apparatus function in the coördination of all the several groups of organelles with which it is intimately associated? An affirmative reply to the first question wonld assign eitler a supporting or a contractile function to this system, and to affirm the seeoud question is to attribute to the system the function of conductivity.

The experimental evidences set forth in previous paragraphs support an affirmative answer to the second question, viz., that this fibrillar apparatıs exhibits features of conduetivity funetioning to coördinate the groups of external organelles with which its unified and dissoeiated parts are directly or indirectly intimately associated. These evidences, furthermore, do not support the assumption that the system is either contractile or supporting in function.

The facts which concern these three propositions may be stated as follows :

The fibrillar system in $\mathrm{E}$. patella is not skeletal or supporting in function.-The rigid, fairly tongh pellicle is amply sufficient to maintain the normal shape of the body under considerable stress. It was 
shown that the pressure of a very flexible needle when applied to the full width of the body did not alter the normal shape of the animal. Also, when the body was flattened for a few minutes by applying a stiffer needle, or by surface tension, upon releasing the stress the body at once recovered. It was also stated that the pellicle was suffieiently tough to require in dissections the use of needles with fairly stiff, sharp points. Other needles were ineffective. Furthermore, the firmness of the pellicle is sufficient to preserve the normal shape of the body after an incision fully two-thirds its width had been made. The friction of water, induced by the animal's continuous and devious swimming movements, effected no visible change in its shape. Any momentary modification in the shape of $\boldsymbol{E}$. patella ean result only from extraneous pressure. Unlike Paramoecium, which readily forces its way through narrow meshes of silk fibers with distinct constrictions of the body, this animal, owing to the consistency of its pellicle, is of itself unable to alter its form.

The basal plate and not the fiber plate is the means of secure attachment and support for both the cirri and the membranelles. The rootlets of the component eilia of both membranelles and cirri are imbedded in the gelatinous eetoplasmie basal plate and are only contiguous with, but not attaehed to, the fiber plate. The readiness with which the basal plate becomes detached from the fiber plate and the want of any indications that the eiliary rootlets had been attached to the smooth, clean fiber plate, was previously deseribed.

The consistency, solubility, size, and shape of the fibers are incompatible with effieient structures for support. Particularly are the anal cirri fibers frail, readily flexible, and irresilient. They may be. pulled in two or bent varionsly with the needle-point. When entirely free from the ectoplasm they are not resilient and, by means of the needle, they may be readily distorted. They may adhere to the needle and thus be pulled about through the water. Their dissolution is sometimes rapid and usually oceurs within fifteen minutes or less after being exposed to the water. It is probable that they are not imbedded in the ectoplasm but lie upon its inner surface, being supported there by a thin, hyaloplasmie sheath. This loose attachment, together with the extensive length and the minuteness of these fibers, indicate that they do not funetion as supporting structures either for the pellicle, which is of itself distinctly firm and resistant, or for the cirri, whose component cilia are not attached to, but only contiguous with, the basal plate. 
This fibrillar system is not contractile in function.-The eontractility either of eirri or of membranelles is not conditioned upon their attachment to the body and consequently not upon any mechanism within the body. All the frontal, ventral marginal and anal cirri and membranelles have distinctly been observed to continue eontractions for a considerable period after their detachment from the body. These reactions liave already been diseussed somewlat at length, and need not be further elueidated here. It is now only worth while to emphasize that their capacity of contraction inlueres within these external organclles themselves. Whether this contractility is effeeted by the basal corpuseles, the axial filament of the eomponent cilia, or the plasmic sheath enclosing the filaments, is not for our consideration.

The loose attachment of the basal plate to the fiber plate indicates that the fibrillar system differs both in structure and in function from the contractile, external organelles. The ease and completeness with which the basal plates beeome detached from the fiber plates and the want of evidenee that the eiliary rootlets and fiber plate are more than merely contiguous struetures are significant features supporting this conclusion.

The consisteney of the anal eirri fibers and their feeble attacliment to the ectoplasm and to the easily displaeed motorium would suggest their meager effectiveness in functioning as contractile struetures. The fibers tend to remain straight when undisturbed. They do not become kinked or curled upon the disintegration of the ectoplasm. It is only by means of the needle or some other external agency that they may readily become distorted. They may be pulled in two with the needle-point but at no time have they shown any indications of stretching.

The reversibly effective strokes of the anal cirri preelude the possibility that the anal cirri fibers are eontractile in function. The four effeetive strokes of these cirri have been described in foregoing paragraphs. These are: (1) direetly baekward strokes parallel to the sagittal plane, (2) directly forward strokes parallel to that plane, (3) laterally backward strokes hardly parallel to the frontal plane, and (4) similar lateral strokes directed forward. All these strokes have been seen many times in the anal cirri of a transected posterior pieee as well as after an incision which lad clearly severed the anal eirri fibers. Since contractile fibers can opcrate effectively only in one direetion, it is inconceivable that an anal cirri fiber ean function as a eontraetile organelle. 
The fibrillar system in Euplotes patclla does possess properties of conductivity functioning to coördinate the movements of the external organclles with which it is associated.-Normal, coördinated aetivity of the series of membranelles is effected through the motorium, the membranelle fiber and its attached membranelle plates. An ineision at any point through the oral lip, which did not sever the membranelle fiber, gave negative results. But when the membranelle fiber was severed, there were conspicuous changes in rhythmie movernents of the membranelles on either side of the incision and distinet modifications in the animal's swimming movements. It was stated that the membranelles on the right side, whose fiber remained conneeted with the motorium, at times beeane inaetive and projected straight out from their base; only oeeasionally were they seen to move in apparent coördination with those on the left side of the incision. The latter, the fiber of which had lost its eomnection with the motorium, showed continuous movements with their effeetive stroke mostly such as normally tends to drive the animal forward. This tendeney in the rate of movement and in the direction of the effective stroke is comparable with the unchanging, ceaseless movements of the adoral membranelles of the excised oral lip which continually moved in cireuits to the right and was never observed to reverse the effective stroke of the adoral membranelles. This constaney in the behavior of membranelles whose fibrillar connection with the motorium is severed might suggest that their usual modifieations in direction of stroke and rate of movement may in some way be effected through the motorium. It is furthermore evident that the unusual swimming movements which followed such incisions resulted from the severing of the membranelle fiber.

Effieient, coördinated behavior of the five anal cirri is effected through the normal functioning of the five anal eirri fibers with their attached fiber plates. The effects of severing these fibers at any one of several regions (see Incisions, page 441, above) were distinet and more or less constant. The infrequeney and lack of facility in ereeping which was, at times, obviously initiated by the frontal cirri, and the rare oceurrence of the avoiding reaction were noteworthy changes in the animal's ereeping movements. But more evident were its modifications in swimming. There was a marked tendency toward performing circus movements to the right. Sharp turns to the right were infrequent and in three cases at no time observed. The rapid, backward, avoiding reaction has never been clearly identified after 
the anal cirri fibers had been severed. It is important and significant in this conneetion to recall that the severing of the anal eirri fibers did not ineapaeitate any of the four movements of the anal eirri. Each of these movements has been elearly observed in the anal cirri upon supporting sneh an incised animal, ventral side down. by means of a very Hexible needle against the under surfice of the cover-glass. Oceasional, usual ereeping or swimming movements by the incised animal might, therefore, be expected as oceurring ineidentally. Accordingly, it is the infrequeney of these ocenrrenees and not their absence that suggests the want of coördination and warrants the eonelusion that the fibers are conductive in function.

Perfect and effieient coördination between the series of membranelles and the five anal eirri is aceomplished through the normal functioning of the motorium and its attached fibers. Whether the fibers were ent on botl sides of the motorium or the motorium destroyed by means of the needle-point, the effeets were very much the same. The usual swimuing movements were more distinctly altered than were the ereeping movements. Changes from normal conditions were the rarity of ereeping movements, their slow rate, very infrequent avoiding reaetions and the tendeney of the animal when not swimming to remain quite passive on débris and umusually irresponsive to mechanical stimuli. The most common reactions in swimming were the right eireus movements, which, here, were more often combined with abnormal, spiral revolutions in which the anterior deseribed much wider spirals than did the posterior end. In no case was the backward swimming reaetion observed, although, as described above, the reversal of both the adoral membranelles and the anal eirri was clearly seen. It will be reealled that when the anal eirri fibers were cut very conspieuous effects were seen in the want of concomitaney and coördination between the movements of the membranelles and of the anal cirri. This, perhaps, showed more clearly than any other experimental eviclences that this fibrillar complex is coördinative in funetion.

Perfect and efficient coördination between the series of membranelles and anal cirri is contingent essentially and only upon the motorium with its attached fibrillar complex. Any incisions through any region of the body. which did not sever or injure this fibrillar apparatus neither impaired the perfect coördination of the membranelles and anal cirri, nor modified the animal's normal ereeping and swimming movements. Whether tlıese incisions did or did not pass through the maeronucleus, the results were always without 
notcworthy consequences. It is apparent, then, that the destruction of the motorium or the severing of some or all of its attached fibers is alone accountable for modifications in the perfect and efficient coördination between the series of membranclles and the anal cirri. We may, therefore, regard these normal, morphological relationships as conditioning the animal's usual bchavior both in creeping and in swimming.

Previous to the rescarches of Sharp (1914) and Yocom (1918), scveral other investigators had found fibers in certain ciliates, which they believed to represent nervous. elcments. Engelmann (1880) described distinct fibers associated with the peripheral and anal cirri of Stylonychia and concluded that they were nervous in function. Neresheimer (1903) found two separate fibrillar systems in Stentor coeruleus, one of which possessed muscular and the other nervous properties. Their shape, size, sclective staining, and relative positions suggested these distinct functions. Moreover, this author found experimental evidence supporting his interpretations. Lebedew (1908) describes two systems of fibrils in Trachelocerca phoenicopterus. On one side and running parallel to each row of basal corpuscles appeared a smooth, structureless fiber staining light, while another larger, less even and densely staining fiber also ran parallel to the row of corpuscles but on the opposite side. The latter was belicved to be a myoneme and the former was perhaps of nervous function.

Other authors (Bütschli, 1889; Schuberg, 1891; Schröder, 1906; Maier, 1903; Prowazek, 1903; Griffin, 1910) have discredited the "nerve hypothesis" for protozoans and have attributed to such systems of fibers either the function of support or of contractility.

It would seem that these discordant interpretations may owe their origin largely to differences in the more gencral conception of the nature of organization and degree of specialization among the Protozoa. And it is in the forming of this general conception that the qualifying attributes-unicellular, primitive, and simple-assert themselves. In the light of the complex, embryogenic processes that give rise to skeletal, muscular and ncural tissues in the many-celled animals, it is not easily conceivable how a single, undivided, simple and primitive "cell"'-the protozoan-could evolve organs performing these specialized functions. Furthermore, it is evident that many protozoans are similar in general appearance and in method of division to a single metazoan ccll; both are defined as "a mass of protoplasm containing nuclear substance (cliromatin) concentrated into one or more 
nuclei"' (Minehin, 19I2, p. 1). Metazoan organs are composed of many eells which have beeome modified and often highly specialized to form tissues, of which several kinds may appear in the same organ. On the other hand, organs of the Protozoa are not eomposed of cells but are modifications of a single cell. We might, therefore, regard the protoplasm within the organs of the protozoan as luaving the same gencral plyysiological properties as the protoplasm throughout the protozoan body and these general properties should be possessed in common with those of any protoplasm wherever found.

Now one general property of all protoplasm is the propagation througlout all its substanec of an excitation effected by a stimulus. 'The morphological continuity of this substance into all the parts or organs of the protozoan body would appear to be the only essential condition for the conduction of an excitation, wherever initiated, to any such part or organ. If this condition is evident in all protozoans, it would scem that specialized, conductive structures for the transmission of exeitations were unessential and useless. Aceordingly, caution in ascribing a nervous function to a structure or a system of struetures in a protozoan body is justifiable.

However, may not as much be said for other general properties of protoplasm? Chambers (1917a) has shown that the surface layer of marine eggs may be pulled out into long strands "without otherwise disturbing the contour of the cell. On being released the strands tend to curl and retract slowly until they disappear" (p. 6). Similar phenomena may be readily demonstrated in the cndoplasmic globules of $E$. patella that frequently form with the escape of the endoplasm into the water. Also, the proverbial amoeba and many of its relatives display the phenomenon of contractility in normal behavior, as do also all amoeboid eclls of the Metazoa. And the eytoplasm of amocbae possesses no fibrils or other specialized structures, so far as is known, by which it effects contraction. Nevertheless, this general property of the cytoplasm is not functioned by such simple and primitive means in many protozoans. It is a well-established fact that in the so-called higher forms contractility is effected mainly, though perhaps not exclusively, by specialized structures, the myonemes.

If, therefore, in the "unicellular" protozoan the general property of contractility has become more or less localized in special organelles, what should restrain conductive protoplasm from the specialization of structures to facilitate conductivity? The extreme rapidity with which many protozoans react to stimuli suggests the presence of 
specialized, condueting elements in their protoplasm. That sueh elements in the ciliate, Euplotes patella, liave become unified into an effieient, integrated system for the coördination of its associated oganelles, is supported, it is believed, hy experimental evidenees set forth in foregoing paragraphs.

Should further experimentation substantiate these results, then their signifieance is clear. The most salient feature of structures and functions in the Protozoa as in the Metazoa is not cellularity but organization. The external organelles of a protozoan body are not mere continuations of the protoplasm as the fingers are a part of the glove. They are rather modifieations which are sometimes distinetly specialized, as the eirri and membranelles of $E$. patella elearly indieate. Moreover, the complex, integrated filbrillar apparatus of this organism signifies higher speeialization in its intracytoplasmie struetures. From these considerations it would follow that any general conception of the Protozoa which assumes that any and all of this extensive and diversified group of organisms are so simple and primitive as to lack speeific organization-the specialization of intra- and extracytoplasmic organelles-is inadequate and will assuredly be abandoned.

\section{SUMMARY}

The fibrillar system in Euplotes patella, found and deseribed by Yoeom (1918) as a "neuromotor apparatıs," has been identified in the living organism both with and without the aid of vital dyes.

Other structures of this system not previously described are: (a) membranelle fiber plates, eaeh of which is eontiguous with a membranelle basal plate and is attaehed at one end to the membranelle fiber;

(b) dissoeiated fiber plates contiguous with the basal plates of the frontal, ventral and marginal cirri, to each of which are attaehed the "dissociated fiber's."

The rectangular anal fiber plates. a modifieation of the posterior ends of the anal fibers, direetly approximate the basal plates of the anal eirri.

The fairly rigid pelliele is amply suffieient to maintain the normal shape of Euplotes under considerable stress and after an ineision fully two-thirds the width of the body has been made. 
The contractility of cirri or of membranelles is not contingent upon their attachment to the body and consequently not upon any mechanism within the body.

The normal locomotion of Euplotes patella includes three creeping movements: (1) straight ahead, (2) a quick backward movement, (3) a turn to the right (aborally); and six swimming movements: (1) forward without spiral revolutions, (2) forward in spiral revolutions, (3) circus movement to the right, (4) circus movement to the left (orally), (5) a sharp turn to the right, (6) rapidly backwards without revolutions.

It was evident from transections of the body and excision of parts that the frontal cirri or anal cirri are indispensable to normal creeping movements, that the adoral membranelles are largely responsible for swimming movement 3 , that the anal cirri function ehiefly in performing creeping movement 2 and swimming movement 5 , and that the adoral membranelles and anal cirri coöperate to effect swimming movement 6 .

Cutting the membranelle fiber results in conspicuous differences in the behavior of the adoral membranelles on either side of the incision and in abnormal spiral revolutions in swimming.

Severing the anal cirri fibers affects both creeping and swimming. Creeping movement 2 is infrequent. Swimming movement 5 was seldom observed and 6 was never seen after the fibers had been severed.

Destroying the motorium or cutting its attached fibers interrupts coördination in the movements of the adoral membranelles and anal cirri.

Any incision not severing either the membranelle fiber or the anal cirri fibers does not impair normal ereeping or swimming movements.

These experimental evidences do not support the assumption that the fibrillar system in Euplotes patella is either contractile or supporting in function, but they indicate that this complex system of fibers does possess conductive properties functioning in the coördination of the movements of the locomotor organelles with which it is intimately associated. 


\section{LITERATURE CITED}

Alexeiefr, A.

1912. Sur la revision du genre Bodo Ehrg. Arch. f. Prot., 26, 413-19, 1 fig. in text.

BARBER, M. A.

1914. Tho pipette method in the isolation of single microorganisms and in the inoculation of substances into living cells. Philippine Jour. Sci., 9, 307-58, 19 figs. in text.

Benda, C.

1899. Weitere Mitteilung über die Mitochondrien. Areh. f. Anat. und Physiol. (Phys. Abt.), Jahrg. 1900, 166-78.

BOECK, W. C.

1917. Mitosis in Giardia microti. Univ. Calif. Publ. Zool., 18, 1-26, pl. 1.

Braune, R.

1913. Untersuchungen ïber dic in Wiederkäuermagen vorkommenden Protozoen. Arch. f. Prot. 32, 5-63, pls. 3-6.

BÜTSCHLI, O.

1885. Einige Bemerkungen über gewisse Organisationsverhältnisse der sog. Cilioflagellaten und der Noctiluca. Morphol. Jahrb., 10, 529-77, pls. 26-28, 4 figs. in text.

1889. Protozoa. Bronn's Klassen und Ordnungen des Thier-Reichs., 1 (3), 1783-95.

Calkins, G. N.

1911. Regeneration and cell division in Uronychia. Jour. Exp. Zool., 10, $95-116,15$ figs. in text.

Chambers, R., JR.

1914. Some physical properties of the cell nucleus. Science, n.s., 40, 824827.

1915. Microdissection studies on the physical properties of protoplasm. Lancet-elinie, Cincinnati, Mareh 27.

1917a. Microdissection studies. I. The visible structure of cell protoplasm and death changes. Amer. Jour. Physiol., 43, 1-12, 2 figs, in text.

1917b. Microdissection studies. II. The eell aster: a reversible gelation phenomenon: Jour. Exp. Zool., 23, 483-505, pl. 1.

1918. The mierovivisection method. Biol. Bull., $34,121-136,8$ fgs. in text.

DOBELL, C. C.

1909. Chromidia and the binuclearity hypothesis. Quart. Jour. Mier. Sci., $53,279-326,25$ figs. in text.

DOFLeIN, F.

1911. Lehrbuch der Protozoenkundo (Jena, Fischer), ed. 3, xii, 1043, 931 figs. in text.

ENGelmani, T. W.

1879. Physiologie der Protoplasma- und Flimmerbewegung. Hermann's Handbuch der Physiol., 1, 341-408, 5 figs. in text.

1880. Zur Anatomie und Physiologie der Flimmerzellen. Pflüger's Arch. f. d. ges. Phys., 23, 505-535, pl. 5. 
ERHARD, H.

1910. Studien über Flimmerzellen. Areh. f. Zellforseh., 4, 310-427, pls. $22,23,16$ figs. in text.

Fischer, A.

1894. Über die Geisseln einiger Flagellaten. Jahrb. f. wiss. Botan., 26, 187235, pls. 11, 12.

GRIFFIN, L. E.

1910a. Euplotes worcesteri sp. nov. I. Strueture. Philippine Jour. Sci., 5, 291-312, pls. 1-3, 13 figs. in text.

1910b. Euplotes worcesteri sp. nov. II. Division. Ibid., 315-36, pls. 4-8.

Gürwitz, A.

1904. Morphologie und Biologie der Zelle (Jena, Fischer), 437 pp., 239 figs. in text.

Hennegux, L. F.

1898. Sur le rapports des eils vibratiles avee les eentrosomes. Areh, d'Anat. Micr., 1, 481-96, 10 figs. in text.

JANICKI, C.

1915. Untersuchungen an parasitisehen Flagellaten. II. Die Gattungen Devescovina, Parajoenia, Stephanonympha, Calonympha. Zeitsehr. wiss. Zool., 112, 573-689, pls. 13-18, 17 figs. in text.

JENNINGS, H. S., AND JAMIESON, C.

1902. Studies on reactions to stimuli in unicellular organisms. X. The movements and actions of pieces of ciliate Infusoria. Biol. Bull., 3, 225-34, 4 figs. in text.

JOSEPH, H.

1903. Beiträge zur Flimmerzellen- und Centrosomenfrage. Arb. a. d. Zool.

Inst. Univ. Wien, 14, 1-81, pls. 1-3, 3 figs. in text.

KHAINSKY, A.

1910. Zur Morphologie und Physiologie einiger Infusorien (Paramoecium caudatum) auf Grund einer neuen histologischen Methode. Arch. f. Prot., 21, 1-60, pls. 1-3, 2 figs. in text.

Kite, G. L.

1912. The nature of the fertilization membrane of the egg of the sea urehin (Arbacia punctulata). Seience, n.s., 36, 562-64.

$1913 a$. The relative permeability of the surface and interior portions of the eytoplasm of animal and plant cells. Biol. Bull., 25, 1-7.

1913b. Studies on the physical properties of protoplasm. I. The physical properties of protoplasm of eertain animal and plant cells. Amer. Jour. Physiol., 32, 146-64.

KIte, G. L., AND Chambers, R., JR.

1912. Vital staining of chromosomes and the function and structure of the nucleus. Science, n.s., 36, 639-41.

KLEBS, G.

1881. Über die Organisation einiger Flagellatengruppen und ihre Beziehungen zu Algen und Infusorien. Untersuch, aus d. Botan. Inst. zu Tübingen, 1, 233-362, pls. 2, 3.

Kolacev, A.

1910. Über den Bau des Flimmerapparates. Areh. mikr. Anat., 76, 349-72, pl. 17, 2 figs. in text. 
KöLSCH, KARL.

1902. Untersuchungen über die Zerfliessungserseheinungen der eiliaten Infusorien. Zool. Jahrb. Abt. f. Anat. u. Ontog., 16, 273-422, pls. $26-$ 28,5 figs. in text.

Kofom, C. A., And Ciristiansen, E. B.

1915a. On Giardia microti, sp. nov., from the meadow mouse. Univ. Calif. Publ. Zool., 16, 23-29, 1 fig. in text.

1915b. On binary and multiple fission in Giardia muris (Grassi). Ibid., 16, $30-54$, pls. 5-8, 1 fig. in text.

KoFord, C. A., AND SWEZY, O.

1915. Mitosis and multiple fission in trieliomonad flagellates. Proc. Amer. Acad. Arts and Sei. Boston, 51, 289-378, pls. 1-8, 7 figs. in text.

LEBEDEW, W.

1908. Uber Tracheloccrea phoenieopterus Coln. Ein marines Infusor. Areh. f. Prot. $13,70-114$, pis. $7,8,7$ figs. in text.

LENHOSSEK, M. v.

1898. Über Flimmerzellen. Verh. d. anat. Ges.

MAIER, H. N.

1903. Ueber den feineren Bau der Wimperapparate der Infusorien. Arch. f. Prot., $2,73-179$, pls. 3,4 .

MarTin, C. II.

1913. Further observations on the intestinal Trypanoplasma of fishes. Quart. Jour. Micr. Sei., 59, 175-193, pls. 9, 10, 2 figs. in text.

MaUpas, E.

1883. Contribution à l'étude morphologique et anatomique des infusories eiliés. Areh. Zool. Exp. et Gen., (2), 1, 427-664, pls. 19-24.

MINCIIN, E. A.

1912. An introduetion to the study of the Protozoa (London, Arnold), xi, 520 pp., 194 figs. in text.

MINKIRWIEZ, R.

1901. Studies on the Protozoa of the Black Sea. I. The organization, multiplieation and systematie position of the genus Euplotes Ehrbg. (In Russian, with a résumé in French.) Trudi Kazan Univ., 35, 1-67, pls. $1,2$.

Mobius, $\mathrm{K}$.

1887. Über die Theilung des Euplotes harpa, Sitzungsber. đ. Ges. nat. Freunde Berlin, 1, 102-103.

NERESHEIMER, E. R.

1903. Die Ilöhe listologischer Differenzierung bei heterotrichen Ciliaten. Arch. f. Prot., 2, 305-24, pl. 7, 1 fig. in text.

PeARL, R.

1900. Studies on electrotaxis. I. On the reactions of eertain Infusoria to the electric current. Amer. Jour. Physiol., 4, 96-123, 7 figs. in text.

Peter, K.

1899. Das Centrum für die Flinmer-und Geisselbewegung. Anat. Anz., 15, 271-283, 4 figs. in text.

Prenant, A.

1914. Les appareils ciliés et leurs dérivés. Jour. d'Anat. et de Physiol. 
ProWAZEK, $\mathrm{S}$.

1903. Protozoenstudien, III. Euplotes harpa. Arb. Zool. Inst., Univ. Wien, $14,81-88$, pl. 1.

PütTter, Aug.

1900. Studien über Thigmotaxis bei Protisten. Arch. f. Anat. u. Physiol., Physiol. Abth., 1900, Supplementband, pp. 243-302, 11 figs. in text. 1903. Die Flimmerbewegung. Ergebn. d. Physiol., 2, 1-102, 15 figs. in text.

ROTHERT, W.

1894. Über das Schicksal der Cilien bei den Zoösporen Phyeomyeeten. Ber. der deutseh. Botan. Gesellsch., 12, 268-82, pl. 1.

SAGUCHI, S.

1917. Studies on eiliated cells. Jour. Morph., 29, 217-268, pls. 1-4, 1 fig. in text.

Schimling, A. J.

1891. Die Süsswasser- Peridineen. Flora oder allgem. Bot. Zeitung. Neue Reihe, $49,220-299$, pls. 8-10.

SCHROEDER, O.

1906. Beiträge zur Kenntnis von Stentor coeruleus Ehrbg. und Stentor roeselli Ehrbg. Arch. f. Prot., 8, 1-16, pl. 1, 1 fig. in text.

Schuberg, A.

1891. Zur Kenntnis des Stentor coeruleus. Zool. Jahrb., 4, 197-238, pl. 14.

SEIFRIZ, W.

1918. Observations on the strueture of protoplasm by aid of mierodissection. Biol. Bull., 34, 307-24, 4 figs. in text.

SHARP, R.G.

1914. Diplodinium ecaudatum with an aceount of its neuromotor apparatus. Univ. Calif. Publ. Zool., 13, 43-122, pls. 3-7, 4 figs. in text.

SIMROTH, H.

1876. Zur Kenntnis des Bewegungsapparates der Infusionsthiere. Areh. mikr. Anat., 12, 51-86, pl. 9.

Stuart, A.

1867. Uber die Flimmerbewegung. Inaug.-Diss. Dorpat, 1-45.

Swezy, O.

1916. The kinetonucleus of flagellates and the binuclear theory of Hartmann. Univ. Calif. Publ. Zool., 16, 185-240, 58 figs. in text.

WALLENGREN, H.

1901. Zur Kenntnis des Neubildungs- und Resorptions- Process bei der Theilung der hypotrichen Infusorien. Zool. Jahrb., Abth. f. Anat., $15,1-58$, pl. 1, 28 figs. in text.

WHITMORE, E. R.

1911b. Studien über Kulturamoeben aus Manila. Arch. f. Prot., 23, 81-93, pls. 3,4 .

WILSON, C. W.

1916. On the life history of a soil amoeba. Univ. Calif. Publ. Zool., 16. 241-92, pls. 18-23.

Үосом, Н. В.

1918. The neuromotor apparatus of Euplotes patella. Univ. Calif. Publ. Zool., $18,337-396$, pls. $14-16,1$ fig. in text. 


\section{EXPLANATION OF PLATES}

\section{PLATE 29}

Fig. 1. Transverse incision through three-fourths of the body, after which the animal maintained normal form. $\times 800$. a.c., anal cirrus; a.c.f., anal cirri fiber; ant. cyt. f., and $m b$. f., membranelle fiber; c.v., contractile vacuole; cyt., cytostome; f.c., frontal cirri; m.c., marginal cirri; mac., macronucleus; m.f.p., membranelle fiber plate; mic., micronucleus; mot., motorium; o.l., oral lip; ph., pharynx.

Fig. 2. Transection between "group of three" and "group of four" frontal cirri. Dorsal view. $\times 800$.

Fig. 3. Transection between "group of four" frontal eirri and the two ventral eirri. $\times 800$.

Fig. 4. Transection between the two ventral cirri and five anal cirri. 

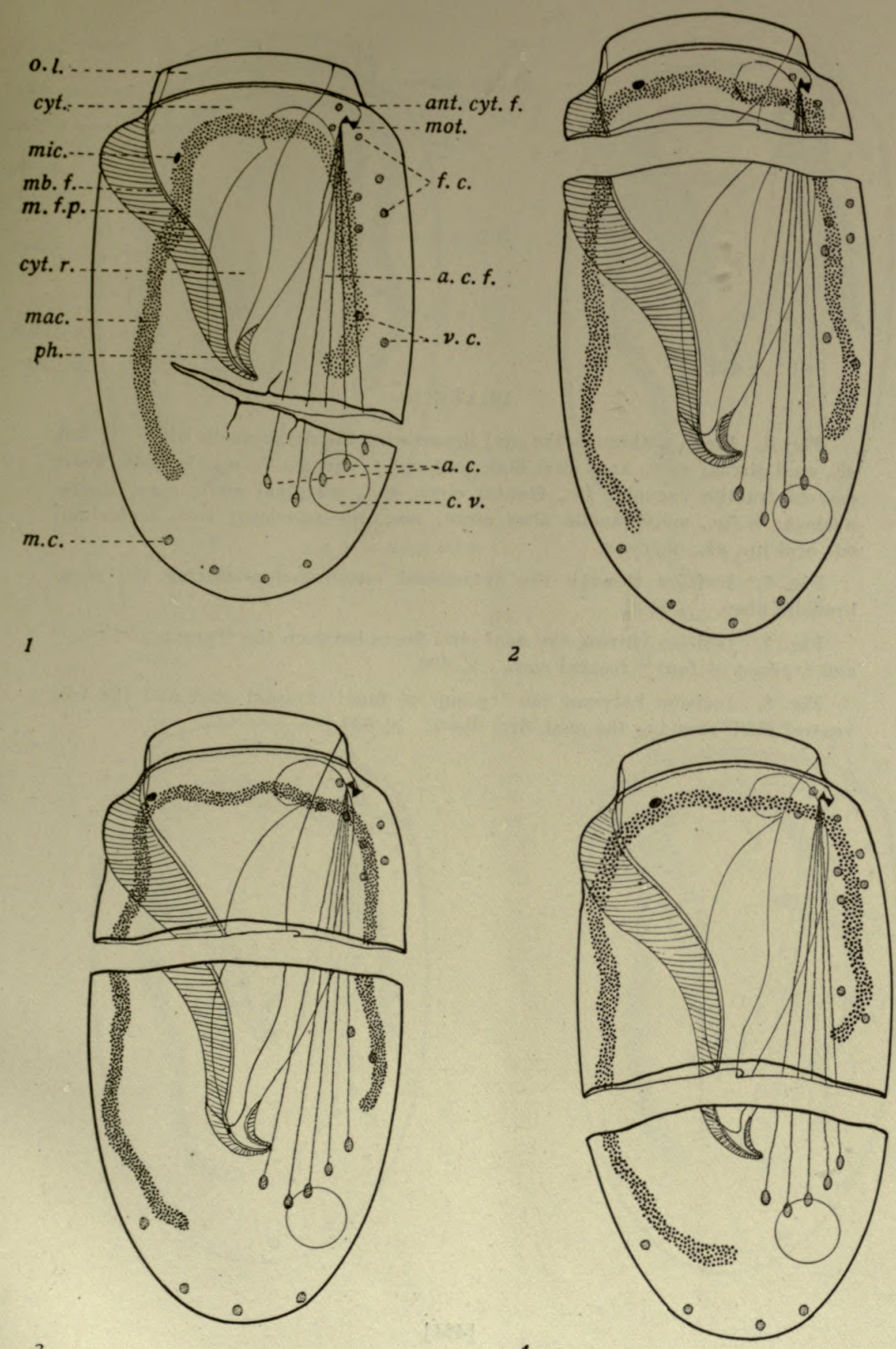


\section{PLATE 30}

Fig. 5. Incision through the oral lip severing the membranelle fiber. $\times 800$. $a c$. , anal cirrus; a.c.f., anal cirri fiber; ant.cyt, $f$. and $m b . f$., membranelle fiber; c.v., contractile vacuole; f.c., frontal cirri; m.c., marginal cirri; mac., macronucleus; m.f.p., membranelle fiber plate; mic., micronucleus; mot., motorium; o.l., oral lip; ph., pharynx.

Fig. 6. Incision through the cytostomal membraneles, cutting the membranelle fiber. $\times 800$.

Fig. 7. Incision cutting the anal cirri fibers between the "group of three" and "group of four'" frontal cirri. $\times 800$.

Fig. 8. Incision between the "group of four" frontal eirri and the two ventral cirri, severing the anal eirri fibers. $\times 800$. 

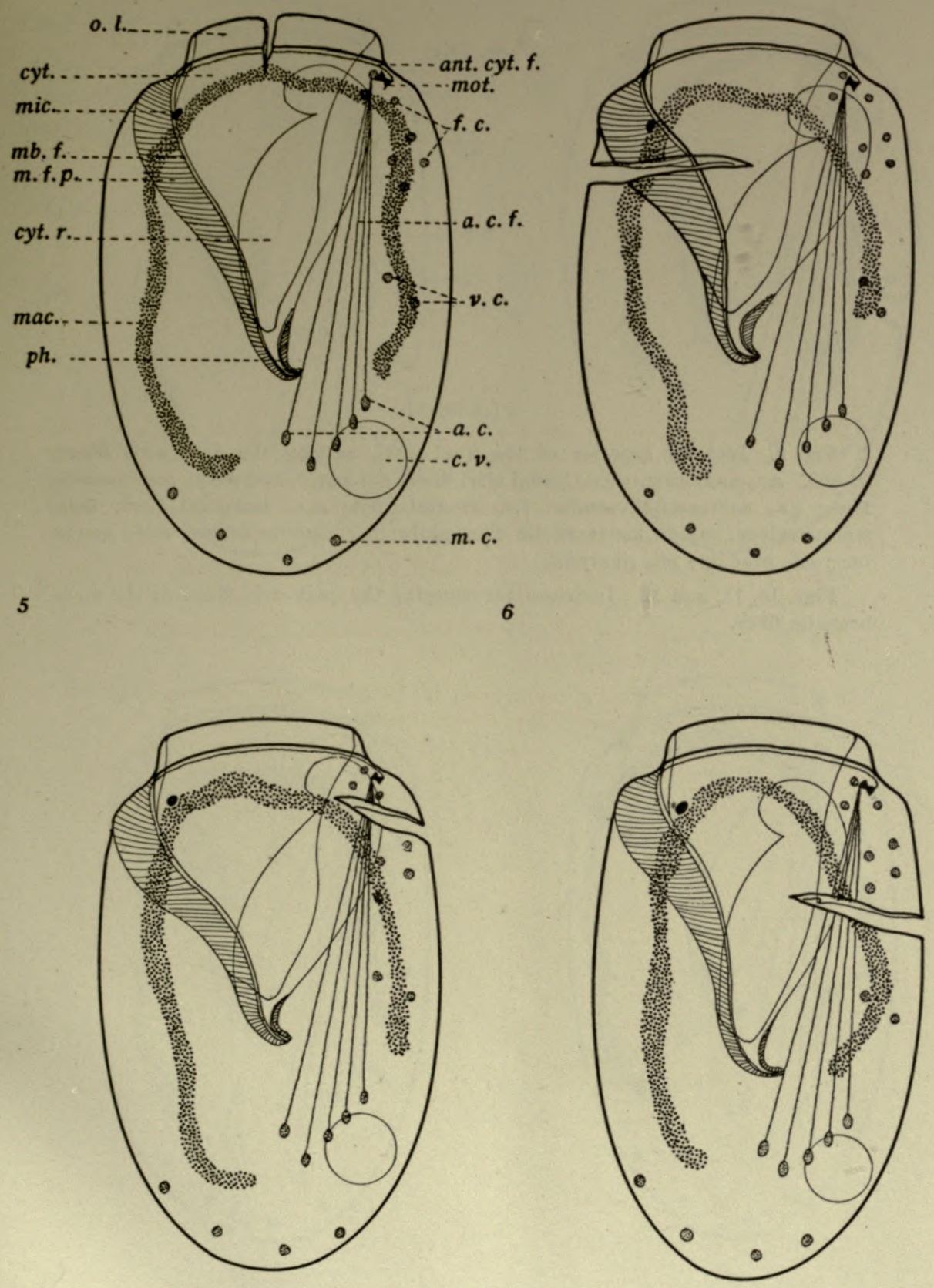


\section{PLATE 31}

Fig. 9. Incision anterior ot the anal eirri, eutting the anal cirri fibers. $\times 800$. a.c., anal eirrus; a.c.f., anal cirri fiber; ant. cyt. $f$. and mb.f., membranelle fiber; c.v., contractile vacuole; f.c., frontal cirri; m.c., marginal cirri; mac., macronucleus; m.f.p., membranelle fiber plate; mic., micronucleus; mot., motorium; o.l., oral lip; ph., pharynx.

Figs. 10, 11, and 12. Incisions not severing the anal cirri fibers or the membranelle fiber. 

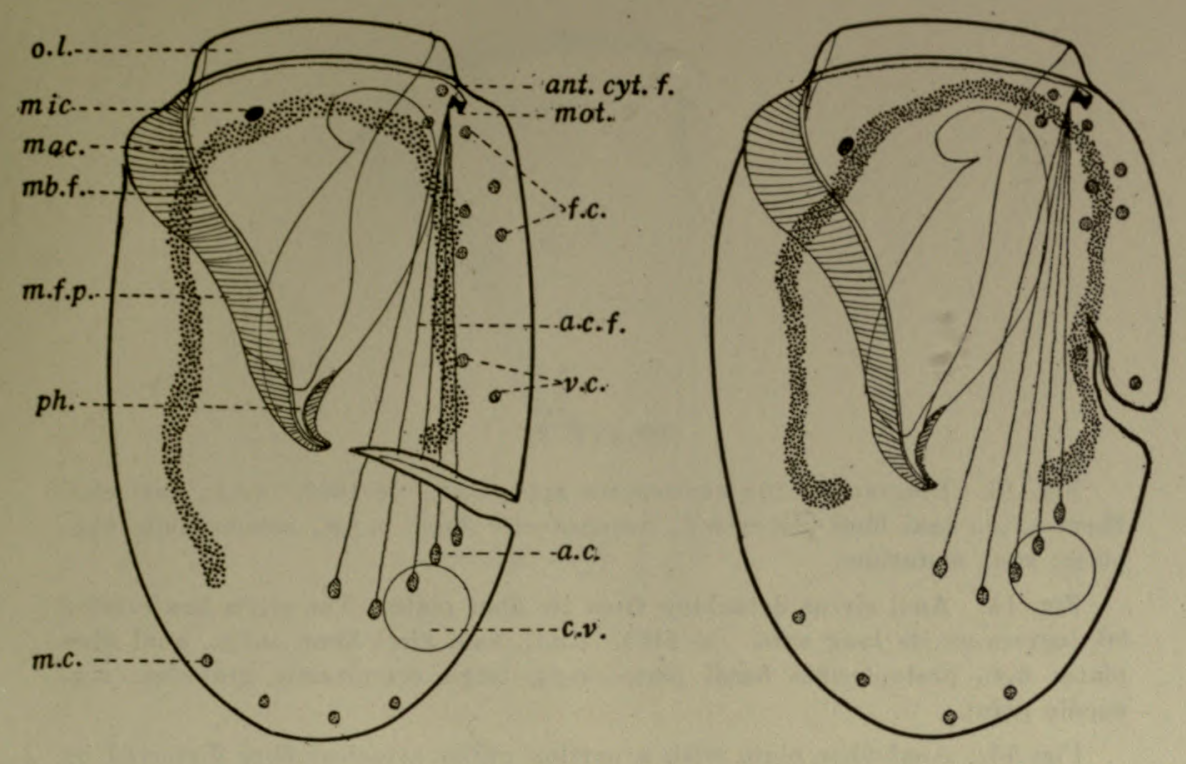

9

10
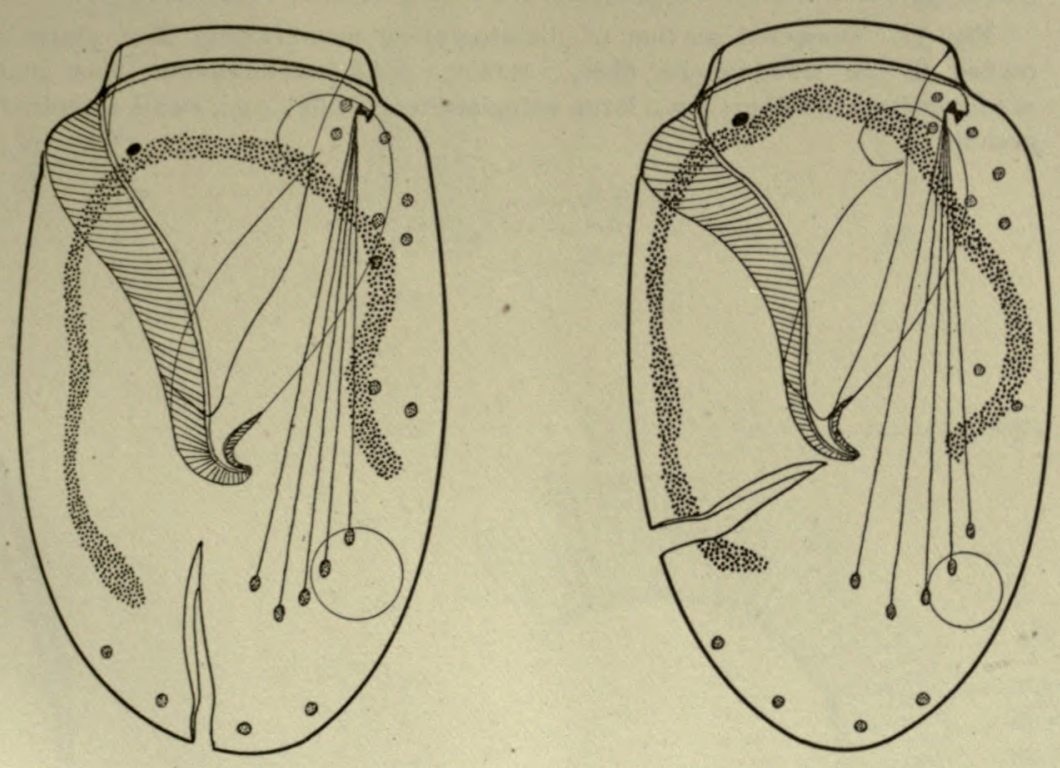


\section{PLATE 32}

Fig. 13. Diagram of the neuromotor apparatus. $\times 1600$. a.c.f., anal cirri fiber; a.f.p., anal fiber plate; m.f., membranelle fiber; m.f.p., membranelle fiber plate; mot., motorium.

Fig. 14. Anal eirrus detaching from its fiber plate. The cirris has rotated 90 degrees on its long axis. $\times 1450$. a.c.f., anal cirri fiber; a.f.p., anal fiber plate; b.p., protoplasmic basal plate; e.g.2, large ectoplasmic granules; n.p., needle point.

Fig. 15. Anal fiber plate with a portion of its attached fiber distorted by the needle point. $\times 1450$.

Fig. 16. Diagram of a membranelle showing its relation to the membranelle plate. $\times 1450$. b.g., basal granule; c.r., ciliary rootlet; f.p., fiber plate.

Fig. 17. Dissected portion of disintegrating membranelle fiber plates attached to the membranelle fiber. $\times 1450$. mf.p., membranelle fiber plate; m.f., membranelle fiber; e.g..2, large ectoplasmic granule; e.g.1, small ectoplasmic granule. 

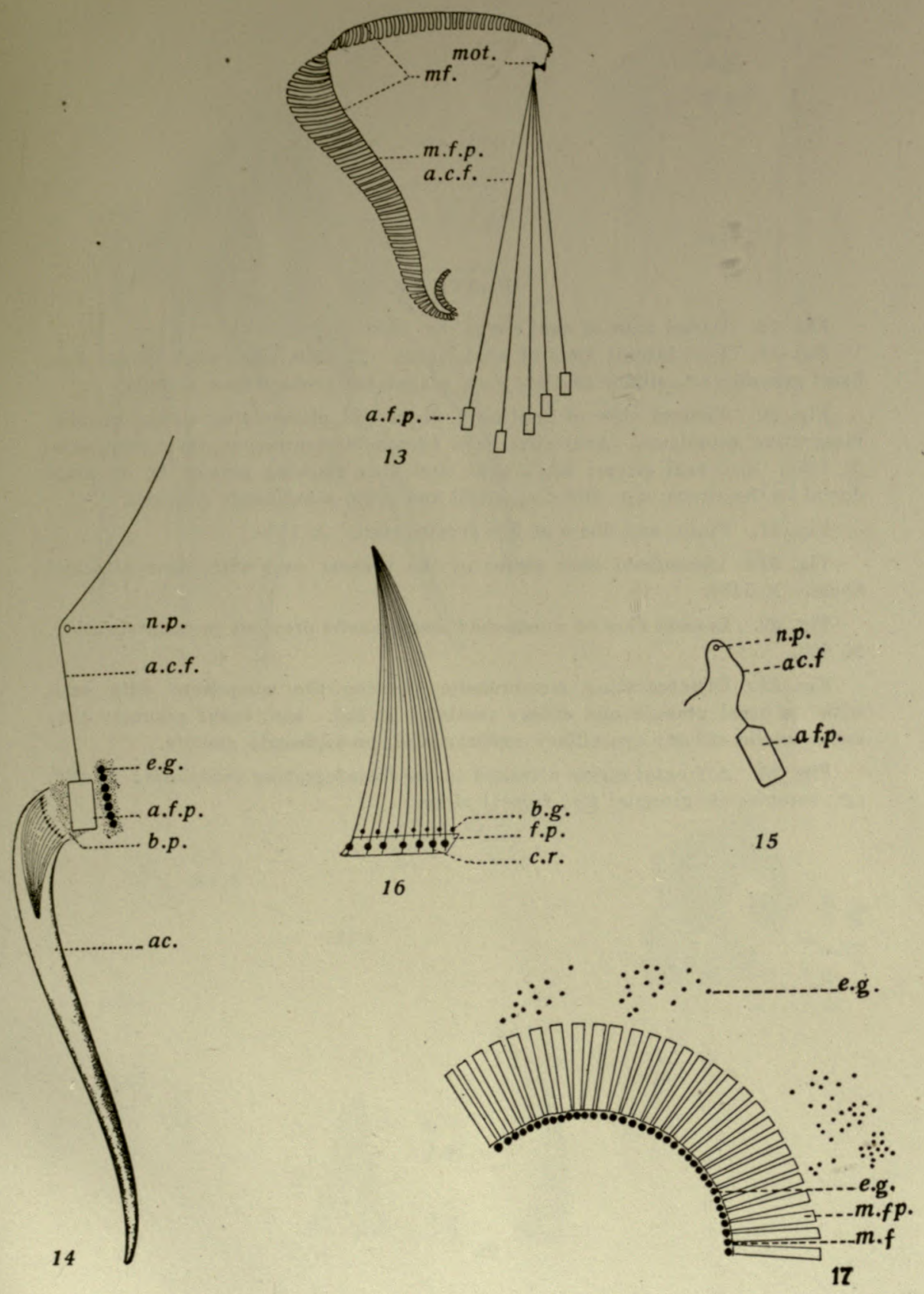


\section{PLATE 33}

Fig. 18. Dorsal view of anal cirrus. $\times 1450$.

Fig. 19. Left lateral view of anal cirrus. $\times 1450$. a.c., anal cirrus; b.g., basal granule; c.r., ciliary rootlet; p.gl., coagulated protoplasmic globule.

Fig. 20. Ventral view of anal cirri, fibers and plates lying among the disintegrating ectoplasm. Anal cirri have turned 90 degrees on their long axis. $\times 1450$. a.c., anal cirrus; a.c.f., anal cirri fiber showing portion of its plate dorsal to the cirrus; e.g. $\cdot_{1}$ and $e . g_{\cdot 2}$, small and large ectoplasmic granules.

Fig. 21. Plates and fibers of five frontal cirri. $\times 1450$.

Fig. 21a. Dissociated fiber plates of the ventral cirri with their attached fibers. $\times 1450$.

Fig. 22. Lateral view of a detached membranelle previous to disintegration. $\times 625$.

Fig. 22a. Disintegrating membranelle showing the component cilia each with its basal granule and eiliary rootlet. $\times 625$. b.g., basal granule; c.m., membranelle eilium; c.r., ciliary rootlet; p.gl., protoplasmic globule.

Fig. 23. A frontal cirrus attached to the disintegrating ectoplasm.. $\times 625$. e.g., ectoplasmic granule; f.c., frontal cirrus. 




\section{UNIVERSITY OF CAITFORNIA PUBLIOATIONB-(Continned)}

11. A study of the Raccs of the White-Fronted Qoose (Anser albifrons) occur. ring io California, by H. S. Swarth and Harold C. Bryant. Pp. 209.222, 2 figures in text, plate 13. October, 1817

12. A Synopsis of the Bats of California, by Hilda Wood Grinnell. Pp. 223-404, plates 14-2f, 24 text figures. January 31,1918

13. The Paclfic Coast Jays of tbo Genus Aphelocoma, by H. S. Swarth. Pp. 405-422, 1 figure in text. February 23, 1918

14. S1x New Mammals from the Mohave Desert and Inyo Reginns of Callfornia, by Joseph Grinuell. Pp. $\$ 23-130$.

15. Notes on Some Bats from Alaska and British Columbla, by IIllda Wood Grinnell. Pp. 431-433.

Nos. 14 and 15 in one cover. Aprll, 1918

18. Revision of the Rodent Genus Aplodontia, by Walter P. Taylor. Pp. 435 504 , plates 25-29, 18 text figures. May, 1918

17. The Subspecies of the Mountain Chlckadee, by Joseph Grinnell. Pp. 505515, 3 text figures. May, 1918

18. Excavations of Burrows of the Rodent Aplofontia, with Observstions on the Hrabits of the Animal, by Charles Lewis Camp. Pp. 517-536, 6 figures in text. June, 1918

Index, pp. $537-5 \pm 5$.

Vol 18. 1. Mitosis in Giarlia microti, by Willam C. Boeck. Fp. 1-26, plate 1. October, 1917

2. An Unnsual Extension of the Distribution of the Shipworm in San Fran. clsco Bay, Califoruia, by Albert I. Barrows. Pp. 27-13. Decembor, 1917.

3. Description of Some Now Species of Polynoidae from the Coast of CallPornia, by Christine Essenberg. Pp. 45-60, plates 2-3. October, 1917 ......

4. New Species of Amphinomidae from tho Pacific Coast, by Christiue Essenberg. Pp. 61-7 $\$$, plates 4-5. October, 1817

5. Crithidia euryophthalmi, sp. nov., from the Hemipteran Bug, Euryophthalmus convirus Stăl, by Irene MicCulloch. Pp. 75-88, 35 text figures. Docember, 1917

8. On the Orientation of Erythropsis, by Charles Atwood Kofoid and Olive Swezy. Pp. 89-102, 12 figures in text. December, 1917

7. The Transmission of Nervous Impulses in Relation to Locomotion in the Earthworm, by John F. Bovard. Pp. 103-131, 14 figures in test. January, 1918

8. The Function of the Giant Fibers in Earthworms, by John F. Bovard. Pp. 135-14t, 1 fgure in text. January, 1918

9. A Rspid Method for the Detection of Protozoan Cysts in Mammallan Eaeces, uy William C. Boeck. Pp. 1\$5-149. December, 1917 .

10. The Musculature of Heptanchus maculatus, by Firie Davidson... Pp. 151-170, 12 figures In text. March, 1918

11. The Factors controlling tho Distribution of the Polynoidae of the Pacific Coast of North America, by Christlne Essenberg. Pp. 171-238, plates 6-8, 2 figures in text. March, 1918....

12. Differentials in Bebavior of the Two Generations of Salpa democratica Relative to the Temperature of the Sea, by Ells I. Michael. Pp. 239-298, plates $9-11,1$ egure in text. March, 1918

13. A Quantitative Analysis of tho Molluscan Fauna of San Franclsco Bay, by E. I. Packard. Pp. 299-336, plates 12-13, 6 figs. in text. Aprll, 1918.....

14. The Neuromotor Apparatus of Euplotes patella, by Harry B. Yocom. Pp. $337-396$, plates $14-16$. September, $1918^{\circ}$

15. The Significance of Skeletal Varlations in the Genus Peridinium, by A. I. Barrows. Pp. 397-478, plates 17-20, 19 figures in text. June, 1918

16. The Subclavian $\nabla$ ein and Its Relations in Elasmobranch Fisbes, by J. Frank Daniel. Pp. 479-484, 2 figures in text. August. 1918

17. The Cercarla of the Japanese Blood Fluke, Schistosoma japonicum Kat surada, by William W. Cort. Pp. 485-507, 3 figures in tert.

18. Notes on the Eggs and Miracidia of the Human Schistosomes, by William W. Cort. Pp. 509-519, 7 figures in text.

Nos, 17 and 18 in one cover. January, 1919 Index in preparation. 


\section{UNIVERSITY OF CALIFORNIA PUBLICATIONS-(Continued)}

V01. 19. 1. Beaction of Varlous Plankton Animals with Beference to their Diurnal Migrations, by Calvin O. Esterly. Pp. 1-83. Aprll, 1919.

2. The Pteropod Desmoptcrus pacificus (sp. nov.), by Christine Essenberg. Pp. 85-88, 2 figures in text. May. 1919

3. Studies on Giardia microti, by Wlllam C. Boeck. Pp. 85-136, plate 1, 19 figures in text

4. A Comparison of the Life Cycle of Crithidia with that of Trypanosoma in the Invertebrate Host, by Irene McCulloch. Pp. 135-190, plates 2-6, 3 figures in text. October, 1919

5. A Muscid Larva of the San Francisco Bay Reglon which sucks the Blood of Nestling Birds, by O. F. Plath. Pp. 191-20c. February, 1919

6. Binary Fission in Collodictyon triciliatum Carter, by Robert Clinton Rhodes. Pp. 201-274, plates 7-14, 4 figures in text. December, 1919 ......................

7. The Excretory System of a Stylet Cercaria, by William W. Cort. Pp. 275281, 1 figure in text. August, 1919

8. A New Distome from Rana aurora, by William W. Cort. Pp. 283-298, 5 figures in text. November, 1919.

9. The Occurrence of a Rock-Boring Isopod along the Shore of San Francisco Bay, California, by Albert L. Barrows. Pp. 299-316, plates 15-17. December, 1919

10. A New Morphological Interpretation of the Structure of Noctiluca, and its Bearing on the Status of the Cystofiagellata (Haeckel), by Charles A. Kofold. Pp. 317-334, plate 18, 2 figures in text. February, 1920 ......

11. The Life Cycle of Echinostoma revalutum (Froelich), by John C. Johnson. Pp. 338-388, plates 19-25, 1 text figure. May, 1920

12. On Some new Myriopods Collected in India in 1916 by C. A. Kofoid, by Ralph V. Chamberlin. Pp. 389-402, plates 26-28. August, 1920

13. Demonstration of the Function of the Neuromotor Apparatus in Euplotes by the Method of Microdissection, by Charles V. Taylor. Pp. 403-470, plates 29-33, 2 figures in text. October, 1920

Vol 20. 1. Studies on the Parasites of the Termites. I. On Streblamastix strix, a Polymastigote Flagellate with a Linear Plasmodial Phase, by Charles Atwood Kofold and Olive Swezy. Pp. 1-20, plates 1-2, 1 figure in text. July, 1919

2. Studies on the Parasites of the Termites. II. On Trichomitus termitidis, a Polymastigote Flagellate with a IHghly Developed Neuromotor System, by Charles Atwood Koloid and Olivo Swezy. Pp. 21-40, plates 3-4, 2 figures in text. July, 1919

3. Studies on the Parasites of the Termites. III. On Trichonympha campanula Sp. Nov., by Charles Atwood Kofoid and Olive Swezy. Pp. 41-98, plates 5-12, 4 figures in text. July, 1919

4. Studies on the Parasites of the Termites. IV. On Leidyopsis spliaerica gen. nov., sp. nov., by Charles Atwood Kofotd and Ollve Swezy. Pp. 99-116, plates 13-14, 1 figure in text. July, 1919.

5. On the Morphology and Mitosis of Chilomastix mesnili (Wenyon), a Common Flagellate of the Fuman Intestine, by Charles $A$. Kofold and Olive Swezy. Pp. 117-144, plates 15-17, 2 figures in text. April, 1920

6. A Critical Review of the Nomenclaturo of Human Intestinal Flagellates, Cercomonas, Chilomastix, Trichomonas, and Giardia, by Charles A. Kofold. Pp. 145-168, 9 figures in text. June, 1920

Vol.21. 1. A Revision of the Microtus californicus Group of Meadow Mice, by Remington Kellogg. Pp. 1-42, 1 figure in toxt. December, 1918

2. Five Now Five-toed Kangaroo Rats from Oalifornia, by Joseph Grinnell. Pp. 43-47. March, 1919

3. Notes on the Natural History of the Bushy-Tailed Wood Rats of California, by Joseph Dixon. Pp. 49-74, plates 1-3, 3 figures in text. Devember, 1919

4. Revision of the Avian Genus Passerella, with Special Reference to the Distribution and Migration of the Races in California, by H. S. Swarth. Pp. 75-224, plates 4-7, 30 figures in text. September, 1920

5. A Study of the Callfornia Jumping Mice of the Genus Zapus, by A. Brazier Howell. Pp. 225-238, 1 text figure. May, 1920

Vol.22. 1. A Quantitative and Statistical Study of the Plankton of the San Joaquin Blver and its Tributarles in and Near Stockton, California, in 1913, by Winfred Emory Allen. Pp. 1-292, plates 1-12, 1 text figure. June, 1920 




\section{NON-GIRCULATING BOOK}

U. C. BER

|||||||||||||||

$\mathrm{CD} 4$

UNIVERSITY OF CALIFORNIA LIBRARY 
